\title{
Economic Crimes against Humanity: a legal challenge for the positive regulation of crimes against humanity in the Article 7 of the Rome Statute
}

\author{
Libia ARENAL*
}

\begin{abstract}
This paper aims to highlight some of the most important challenges that international law will face in the coming decades, namely the possible international criminalization of serious economic abuses -the so called "economic crimes against humanity"- characterised by the violation of basic human values that are recognised and protected by the international community. This article will focus on analysing, on the one hand, the importance of the category of crimes against humanity, as a teleological and normative framework, for a legal development for "economic crimes against humanity" in international law; on the other hand, it will present the difficulties for the inclusion of these serious economic abuses in the regulation of crimes against humanity in Article 7 of the RS Rome Statute, based on the analysis of the common elements of the context in which the conducts must take place - threshold clause or chapeau clause-. It will end with some contributions for the construction of a contextual element for "economic crimes against humanity", on the grounds of the definition of crimes against humanity in the Rome Statute, to become crimes of concern to the international community as a whole.
\end{abstract}

Keywords: crimes against humanity - serious economic abuses - International Criminal Court

\section{(A) INTRODUCTION}

The renowned financial analyst and professor at Harvard University, Shoshana Zuboff, published in 2009 an article entitled "Wall Street's economic crimes against Humanity". 'The author made a plea against the dehumanization of the financial system and pointed out that the crisis, derived from the abuses that had been committed within it, was not only about to destroy the economic foundations of the countries most affected by it, but also had an unexpected and alarming impact on fundamental areas for the lives of millions of people in various regions of the world.

Zuboff underlined in her work that although the economic crisis was not equivalent to the Holocaust, it derived from a business model characterized by the same type of remoteness, lack of reflection and widespread abrogation of individual moral judgment that Hannah Arendt had observed in Adolf Eichmann's behaviour regarding the commission of Nazi crimes. She encapsulated this reflection in the expression "the banality of evil"."

According to Zuboff, this "economic narcissism" paved the way for the execution of a "large-scale administrative economic massacre", showing that the serious nature and consequences of this type of economic abuse lay in the fact that it affects a series of basic and universal human values, recognized

do Article received on 10 July 2020 , accepted on 27 November 2020 and published on ${ }_{31}$ December 2020

* Associate Professor of Public International Law, University of Seville.

' S. Zuboff, "Wall Street's economic crimes against humanity", Businessweek, 20 March 2oo9, accessed II August 2020.

${ }_{2}$ H. Arend, Eichmann en Jerusalén: Un estudio sobre la banalidad del mal (Lumen, 2003)

3 S. Zuboff, supra n.I. 
by the international community with the same gravity as other serious criminal behaviour that had already generated international interest and had been the object of categorizing in the international legal system.

Zuboff's argument, joined by other representatives of academia and professional practice ${ }^{4}$, thus connected serious contemporary economic and financial abuses with crimes against humanity. ${ }^{5}$ This is a category of international crimes introduced by the Statute of the International Military Tribunal of Nuremberg (IMT) after World War II $^{6}$, and after a long evolution has become conventionally defined in Article 7 of the Rome Statute (RS) ${ }^{7}$ of the International Criminal Court (ICC) together with the instrument of the Elements of Crimes. ${ }^{8}$ Likewise, it is important to take into account the work of the International Law Commission (ILC) on a convention on prevention and punishment of crimes against humanity, developed between 2015 and $2019^{9}$. In fact, in this last year, the Commission adopted, on second reading, the Draft Articles on Prevention and Punishment of Crimes against Humanity and decided, in conformity with article 23 of its statute, to recommend the Draft Articles to the General Assembly. ${ }^{\text {1o }}$

The fundamental purpose of the prohibition of crimes against humanity has been to control the abuse of political power of the State against individuals through the commission of acts considered aberrant and inhumane such as murder, extermination, forced displacement, slavery, torture, grave sexual violence, enforced disappearance and other inhuman acts of similar character acts intentionally causing great suffering or serious injury to physical integrity or mental or physical health,

4 L. Benaría and C. Sarasúa, “Delitos y crímenes económicos contra la humanidad”, Revista de Economía Crútica, $\mathbf{n}^{\mathbf{0}}$ 12, Segundo Semestre (2011); J. Torres, “Crímenes económicos contra la humanidad”, published on 27 May 20I3, last access II August 2020; Fundación Internacional Baltasar Garzón (FIBGAR) “Principios de MadridBuenos Aires sobre Jurisdicción Universal”.

5 Statute of the International Military Tribunal of Nuremberg(signed at London, on 8 August I945), accessed II August 2020.

${ }^{6}$ For an analysis of the evolution of this category of crimes see C. Márquez Carrasco, El proceso de codificación y desarrollo progresivo de los crímenes contra la humanidad (Secretariado de publicaciones Universidad de Sevilla, 20o8).

7 Rome Statute of the International Criminal Court, 2187 UNTS $_{3}$ (adopted I July I 998 , entered into force I July 2002).

$8 \quad$ ICC, Elements of Crimes. The Elements of Crimes are reproduced from the Official Records of the Assembly of States Parties to the Rome Statute of the International Criminal Court, First session, New York, $3^{\text {-Io, }}$ September 2002 (United Nations publication, Sales No. E.o3.V.2 and corrigendum), part II.B.

$9 \quad$ At its sixty-sixth session, in 2014, the International Law Commission (ILC) decided to include the topic "Crimes against humanity" in its programme of work, on the basis of the recommendation of the Working Group on the long-term programme of work. The Commission decided to appoint Mr. Sean D. Murphy as Special Rapporteur for the topic who has submitted four reports to the ILC. First report on crimes against humanity By Sean D. Murphy, Special Rapporteur (hereafter "First Report”), UN Doc. A/CN.4/68o, I7 February 20I5; Second report on crimes against humanity By Sean D. Murphy, Special Rapporteur (hereafter "Second Report”), UN Doc. A/CN.4/69o, 2I January 2016; Third report on crimes against humanity By Sean D. Murphy, Special Rapporteur (hereafter "Third Report"), UN Doc. A/CN.4/704, 27 January 20I7; Fourth report on crimes against humanity By Sean D. Murphy, Special Rapporteur (hereafter “Fourth Report”), UN Doc. A/CN.4/725, I8 February 2019.

io See the Draft articles on Prevention and Punishment of Crimes Against Humanity 2019 , adopted by the ILC at its seventy-first session, in 2019, and submitted to the General Assembly as a part of the Commission's report covering the work of that session (A/74/Io), Yearbook of the International Law Commission, 2org, vol. II, Part Two (hereinafter Draft articles). 
when they are committed in the context of a widespread or systematic attack against the civilian population.

Crimes against humanity entail the international criminal responsibility of the individual ${ }^{\mathrm{II}}$, are not subject to a statute of limitations ${ }^{12}$ and must and can be prosecuted by States in the exercise of univer sal jurisdiction ${ }^{13}$, all by virtue of the fact that these crimes constitute an affront to their direct victims and to humanity as a whole ${ }^{14}$.

Although originally the category of crimes against humanity was not intended to prosecuting economic-financial, economic-political or ecological crimes, and to date these kind of crimes have not been identified with crimes against humanity in positive public international law, this does not imply that the elements that make them up do not fit into the category of crimes against humanity. However, if international law once evolved by criminalizing the serious abuses of political power of States committed against their own citizens, something inconceivable until after World War II, today we must consider if it would be possible this category of crimes to move towards an integral protection of the human beings from serious abuses of economic and economic-political power committed by both states and non-state actors.

The objective of this paper is to analyse whether this category of international crimes under the Article 7 of RS of the ICC is from a teleological and juridical-positive perspective adequate to address the serious economic and economic-political abuses resulting from the neoliberal economic globalization and the framework of important changes in the exercise and di stribution of power in the international society.

\section{(B) THE SOCIAL CONTEXT FOR THE EMERGENCE OF THE TERM “ECONOMIC CRIMES AGAINST HUMANITY”}

As we have already said, Shoshana Zuboff formulated the expression "economic crimes against humanity" in the article entitled "Wall Street's Crimes against Humanity". The author pointed out clearly the following: "That in the crisis of 2009 the mounting evidence of fraud, conflicts of interest, indifference to suffering, repudiation of responsibility, and systemic absence of individual moral judgment produced an administrative economic massacre of such proportion that it constitutes an economic crime against humanity" ${ }^{5}$

What is interesting about Zuboff's proposal is that it makes a connection between crimes against humanity, a category of international crimes, and emerging serious economic abuses related with the context of neo-liberal economic globalization. Zuboff believes that this kind of egregious conducts are new risks and threats to fundamental values protected by the international community. In this vein, the concept "economic crimes against humanity" aims to invoke a reflection on the economic

" IMT, Judgement, 30 September, I October 1946, in Trial of the Major War Criminals before the International Military Tribunal, Nuremberg, vol. I (Nuremberg, I948), at 223.

${ }^{12}$ Convention on the non-applicability of statutory limitations to war crimes and crimes against humanity, 754 UNTS 73 (adopted 26 november I968, entered into force I november I970).

I3 Rome Statute (RS), Preamble “[...] is the duty of every State to exercise its criminal jurisdiction over those responsible for international crimes”.

${ }_{1 / 4}$ All these components have been confirmed in the Draft articles on Prevention and Punishment of Crimes Against Humanity 2org, supra n.Iо.

I5 S. Zuboff, supra n.I. 
paradigm as shaping new expression of crimes threatening humanity at this contemporary moment in the history of international society.

"Economic crimes" ${ }^{6}$ is a relatively new concept in international law. In fact, today, it does not exist a general definition of these crimes $^{17}$, neither conventional nor customary law. There is also no agreement on the different conducts that could be included under this expression. ${ }^{18}$ It is only possible to verify a non-exhaustive list of behaviours that qualify as an economic crime under treaty-based international law - i.e. the United Nations Convention against Corruption of $2003^{19}$ including acts of corruption, illicit enrichment, embezzlement, kleptocracy, bribery, money laundering, influence peddling, abuse of functions, falsification, identity theft, tax evasion or tax fraud and cybercrimes.

Bearing in mind these legal limitations on the definition of economic crimes, we must start the study of the expression "economic crimes against humanity" from a broad conception of these crimes: serious abuses by their nature and consequences on fundamental and universal legal values, including human rights ${ }^{20}$; generating significant human, social, environmental and economic damage;

${ }^{16}$ The term "economic crimes" is a translation of the Anglo-Saxon term "economic crimes." The first references to the expression economic crimes, or also the so-called "White-collar crimes", can be found in the works of the sociologist Sutherland, who highlighted how "white collar" crimes were committed through dishonest practices - manipulation of accounts, bribes, embezzlement, tax fraud or embezzlement, among many others in different professions. He also developed the "differential association theory" highlighting that whitecollar criminals often have the cooperation of other actors and significant social or relational capital that serves as coverage. See J. W. Coleman, “Toward an Integrated Theory of White-Collar Crime," American Journal of Sociology, vol. 93, no. 2, September (I987), 406-439 [doi:Io.1o86/228 75 o]. The economist Becker also presented his economic theory of crime in which the criminal is represented as a maximizingagent, which analyses risk factors, reward and punishment when considering the economic and social environment fundamental to the commission of the crime. See G.S. Becker, "Crime and punishment: An economic approach", in Essays in the Economics of Crime and Punishment, UMI, (I974) I-54 (Published online I $_{5}$ October 2015).

${ }^{17}$ Bill McCarthy and Lawrence $E$. Cohen have stated that there is no widely accepted definition of the term economic crime and that it is impossible to list briefly all the definitions, theories, and offenses included in this category, see B. McCarthy and L. E. Cohen, "Economic Crime: Theory", Encyclopedia of Crime and Justice. Along these lines, Barroso González points out that the acceptance of a common definition of economic crime in international Criminal Law is still conflictive. See J. L. Barroso González, "Economic crimes from a criminological perspective”, Journal of the Institute of Legal Sciences of Puebla, Mexico, Year IX, January - June (20I5) 95 -I 22.

${ }_{18}$ B. Zagaris, International White-Collar Crime: Cases and Materials (Cambridge University Press, 2oIo). The author states that economic and financial crime refers to a variety of activities that cannot be included under the same rubric. In the Spanish legal system, for example, "economic crimes" are included in the Criminal Code under different headings. In Title XII the "crimes against heritage and socioeconomic order" are typified, and it is these crimes that are considered the essence of economic crimes. However, there are also crimes of content or economic impact, not included in the previous group, but which end up affecting economic values. With this perspective, they can be included in the group of economic crimes, due to the economic importance of some such as: environmental crimes, since the majority go through a business policy that despise the forecast of environmental damage, which it implies a saving in costs and an increase in benefits, to the detriment of the environmental value, of the value of the affected place itself and of the conditions of fair competition; the crimes of officials with economic significance, for example; corruption, crimes against consumers; crimes against public finance and social security; G. Quintero Olivares, Los delitos económicos (Editorial UOC, S. L. 2oI6); C. M. Buján Pérez, Derecho Penal Económico y de la Empresa. Parte general (Tirant lo Blanch, 2oI6); A. Galán Muñoz and E. Núñez Castaño, Manual de derecho penal, económico y de la empresa (Tirant lo Blanch, 2oI7).

19 United Nations Convention against Corruption, 2349 UNTS 4 I (adopted by the UN General Assembly in October 20o3, entered into force in December 2005).

${ }^{20}$ M. Ollé Sesé, Crimen internacional y jurisdicción penal nacional: de la justicia universal a la jurisdicción 
committed by entities, groups or organizations holding economic and economic-political power and a great capacity to victimize population with impunity.

The expression "economic crimes against humanity" could therefore integrate a long list of different actions. It is worth mentioning a category of "economic-political crimes" ${ }^{21}$ that may be considered conceptually original with respect to this expression "economic crimes against humanity". We are referring to national or international economic and political decisions that can lead to serious and unprecedented social crisis. The impact of the financial crisis of $2008 \mathrm{on}$ human rights resulted in widespread unemployment, loss of housing and social safeguards such as insurance against unemployment, health and education, eroding the living standards of communities, leaving millions of people in poverty. ${ }^{22}$ The global financial and economic crisis also revealed a collective feeling that the people responsible for this behaviour were unpunished by pointing to the market system, as an abstract entity, being primarily responsible for this economic massacre. ${ }^{23}$ In the same vein, we wonder right now about the consequences of the national and international policies adopted in the matter of COVID and its impact on the protection or even the regression of human rights. ${ }^{24}$

Other facts that highlight our thesis are related to the emergence of other crises related with the financial and economic decisions, such as the food crisis linked to the production of biofuels with devastating effects on the poorest populations in the global South countries. ${ }^{25}$ While the United States and the European Union have provided enormous assistance to the agricultural and biofuel industry from 2007 within the framework of their energy diversification policies ${ }^{26}$, the prices of crops or palm

penal interestatal (Thomson Reuters Aranzadi, 20I9), at 554 .

${ }^{21}$ Naucke defines “economic-political crimes," in the context of the 2008 economic and financial crisis, as those politically powerful economic processes that harm individual citizens by destroying vital spheres for their lives, executed by an authoritarian and powerful sector of society that offers enormous resistance to legal responsibility for these economic decisions. See W. Naucke, El concepto de delito económico-político. Una aproximación, (Marcial Pons, 2015).

${ }^{22}$ Report of the Office of the United Nations High Commissioner for Human Rights on the impact of the global economic and financial crises on the realization of all human rights and on possible actions to alleviate it, UN Doc.

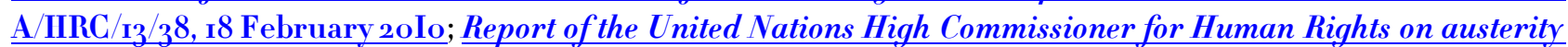
measures and economic and social rights, OHCHR, 7 May 2013; P. Swagel "The Cost of the Financial Crisis: The Impact of the September 2008 Economic Collapse”, Briefing Paper\#I8 Cost of the Financial Crisis. The initial results were presented in the public event, "Financial Reform: Too Important to Fail," sponsored by the Pew Financial Reform Project, i8 March 2oIo.

23 S. Zuboff, supra n.I.

${ }_{24}$ For a broader view see G. L. Gardini (Ed.) The world before and after COVID-Ig. Intellectual reflections on politics, diplomacy and international relations, European Institute of International Studies (SalamancaStockholm, 2020).

${ }^{25}$ K. Paramaguru, “Betting on Hunger: Is Financial Speculation to Blame for High Food Prices?” Science Time, December I7 (20I2); J. L. Vivero Pol and C. Porras Gómez, "Los biocombustibles y su impacto en la crisis alimentaria”, en K. Cascante and A. Sánchez (eds.), La crisis mundial de alimentos: alternativas para la toma de decisiones, Fundación Alternativas. (Exlibris ediciones, Madrid, 20o8), at 29-5 ${ }^{\mathrm{I}}$.

${ }_{26}$ Prosalus (coord.) “Agrocombustibles, ¿Pate del problema o de la solución?” I vol. 86 pp. Prosalus, Veterinarios Sin Fronteras e Ingeniería Sin Fronteras. However, the European Commission is currently conducting an assessment of the impact of ongoing biofuel projects financed by the Union in the countries of Africa, the Caribbean and the Pacific (ACP) that could question the support given to investment projects in Biofuel production from food crops with a view to export to Europe. The European Commission is studying the consequences of biofuel production in developing countries from the point of view of the coher ence of development policies, as evidenced by the commission commissioned study in this regard. Likewise, in the 
oil raised rapidly generating food insecurity, land grabbing and environmental erosion in countries such as Indonesia, Cambodia, Guinea Bissau, Nigeria, Argentina and many more ${ }^{27}$ Multinationals such as Bunge, DuPont, Cargill, ADM or Syngenta controlled more than 70 percent of the supply chains of cereals and impose their prices with the collaboration of financial entities such as Goldman Sachs, JP Morgan, Bank of America, Banco Santander, BBVA and Deutsche Bank, speculating on the price of food. Jean Ziegler, former United Nations Rappor teur on the Right to Food, denounced the increase in basic food prices in 2008 due to speculation, stating that "it is the criminal economic structures that manufacture the daily hunger massacre ${ }^{28}$. He also stated at the end of $20 I_{3}$ that burning tons of crops to produce biofuels was a crime against humanity, since it destroyed resources needed to produce basic food. ${ }^{29}$ In a similar manner, in these days we appreciate how pharmaceutical companies producing the COVID-I9 vaccine raise the value of their shares on the stock market ${ }^{{ }^{\circ}}$ while the World Health Organization (WHO), has called the coronavirus vaccine to be considered a "public good" in its Annual Assembly. ${ }^{31}$ In conclusion, speculation with essential goods for the protection of human life, such as food, but also others such as water, housing, vaccines or medicines, constitutes one of the worst contemporary forms of violation of human rights and a way to attack the population.

Other cases that illustrate our hypothesis are related to state corruption, misappropriation and plundering of public funds or "patrimonicide" ${ }^{32}$ with the consequence of the submission of populations to extreme living conditions while those responsible for that behaviour often go unpunished. ${ }^{33}$ This type of corruption is necessarily linked to the commission of other crimes of an economic nature, including "white collar" crimes, whose expansion has been possible in recent decades due to the construction of a "global space without control" ${ }^{34}$ In it, the freedom of capital flows

United States, there is uncertainty about the viability of the obligatory mixes from the moment it became clear that second-generation biofuels could not replace those produced from food crops as initially thought when adopting such policies. See FAO, Los biocombustibles y la seguridad alimentaria. Un informe del Grupo de alto nivel de expertos en seguridad alimentaria y nutrición del Comité de Seguridad Alimentaria Mundial, HLPE, (Roma, 2013).

${ }_{27}$ J. Ziegler, "Burning food crops to produce biofuels is a crime against humanity", Global development Poverty Matters Blog, The Guardian, 26 November 2013, last access 12 August 2020.

${ }_{28}$ Ibid.

29 Ibid.

zo See N. Dominguez \& I. Fariza, “Especulación millonaria con las vacunas: las farmacéuticas disparan su valor con medicamentos aún sin eficacia demostrara”, EI País (I7 November 2020).

${ }^{3} \quad$ World Health Organization (WHO), Seventy-third World Health Assembly A73/conf./I Rev.I Agenda item 3 I8 May 2020.

$3^{2}$ The term 'patrimonicide' has been used by Ndiva Kofele Kale to refer to this contemporary form of political corruption that not only implies acts of predation against public heritage but also dimensions the destruction of moral, economic and social pillars of the nations that are victims of these practices. See N. K. Kale, "Economic crimes and international justice: Elevating Corruption to the Status of a Crime in Positive International Law" Symposium on Corruption and its Implications for Human Rights Center for Human Rights and Democracy in Africa Alliance Franco-Camerounaise Center, Buea, June $25(2009)$.

33 According to Transparency International "Grand corruption is the abuse of high-level power that benefits the few at the expense of the many, and causes serious and widespread harm to individuals and society. It often goes unpunished. It concerns millions of victims around the world". See information in the report "Transparency international to pursue social sanctions on 9 grand corruption cases. Contest to identify most symbolic cases of grand corruption reached millions of people”, Io February 2 or6, last access 12 August 2020.

34 M. Villoria and J. López Pagán, “Globalización, corrupción y convenios internacionales: dilemas y propuestas para España", Documento de Trabajo $42 / 200923 / 07 / 2009$, Real Instituto El Cano (2009), at 5 , last 
linked to deregulation of markets, lack of transparency, bank secrecy, capital investment in tax havens and other types of conduct outside the law. Among the most significant cases of corruption worldwide, it is worth mentioning the precedents in Equatorial Guinea ${ }^{35}$, Philippines ${ }^{36}$; the Military Regime of the Chilean dictatorship ${ }^{37}$, Venezuela ${ }^{3}$; or, finally, the case of Petrobas, the state-controlled oil giant in Brazil. 39

Other economics abuses called to be included in the expression "economic crimes against humanity" have to do with the global integration of economies, including labour markets, appearing to offer many opportunities for working people and companies, and stimulated economic growth but not equal progress and benefits for all. According to data released by reports of the United Nations Office on Drugs and Crime (UNODC) ${ }^{4^{\circ}}$ and the International Labour Organization (ILO) ${ }^{4 \mathrm{r}}$ millions of people fall victim to trafficking related to organized crime in this growing global market when they are looking for decent jobs. In many cases, vulnerable people are held in in debt bondage or slavery-like conditions, trapped in exploitative labour conditions that keep them in poverty and discrimination. Almost 2I million people are victims of forced labour or near slavery -II.4 million are women and girls, and 9.5 million men and boys-. Individuals or private companies exploit more than I 9 million victims and the state or rebel groups closed to II million. 4.5 million victims suffer forced sexual exploitation.

Trafficking for sexual exploitation, particularly of women and children, is one of the most serious human rights violations that exist and this reality must to be confronted. This wide and growing phenomenon affects "the destiny of the most vulnerable people in the world and is an affront to human dignity and the challenge for each state, all people and every community..$^{2}$ According to the ILO, of the approximately 40 million people who are subject to modern forms of slavery, $4,800,000$ people suffer forced sexual exploitation, of which ninety-nine percent are women. ${ }^{43}$ Forced labour in the private economy generates illegal annual earnings of $\$ \mathbf{5} 50$ billion per year while domestic work, agriculture, construction, manufacturing and entertainment are the most affected sectors. ${ }^{4 t}$

The Rana Plaza collapse case, the complaint against supplier companies in Argentina or Brazil of the spanish Inditex group for practices close to slavery ${ }^{45}$, or the Associated Press of Journalists complaint about abusive practices close to slavery in the fishing industry in Southeast Asia ${ }^{4^{6}}$, are some examples that highlight the perverse functioning of the system and the serious human rights violations

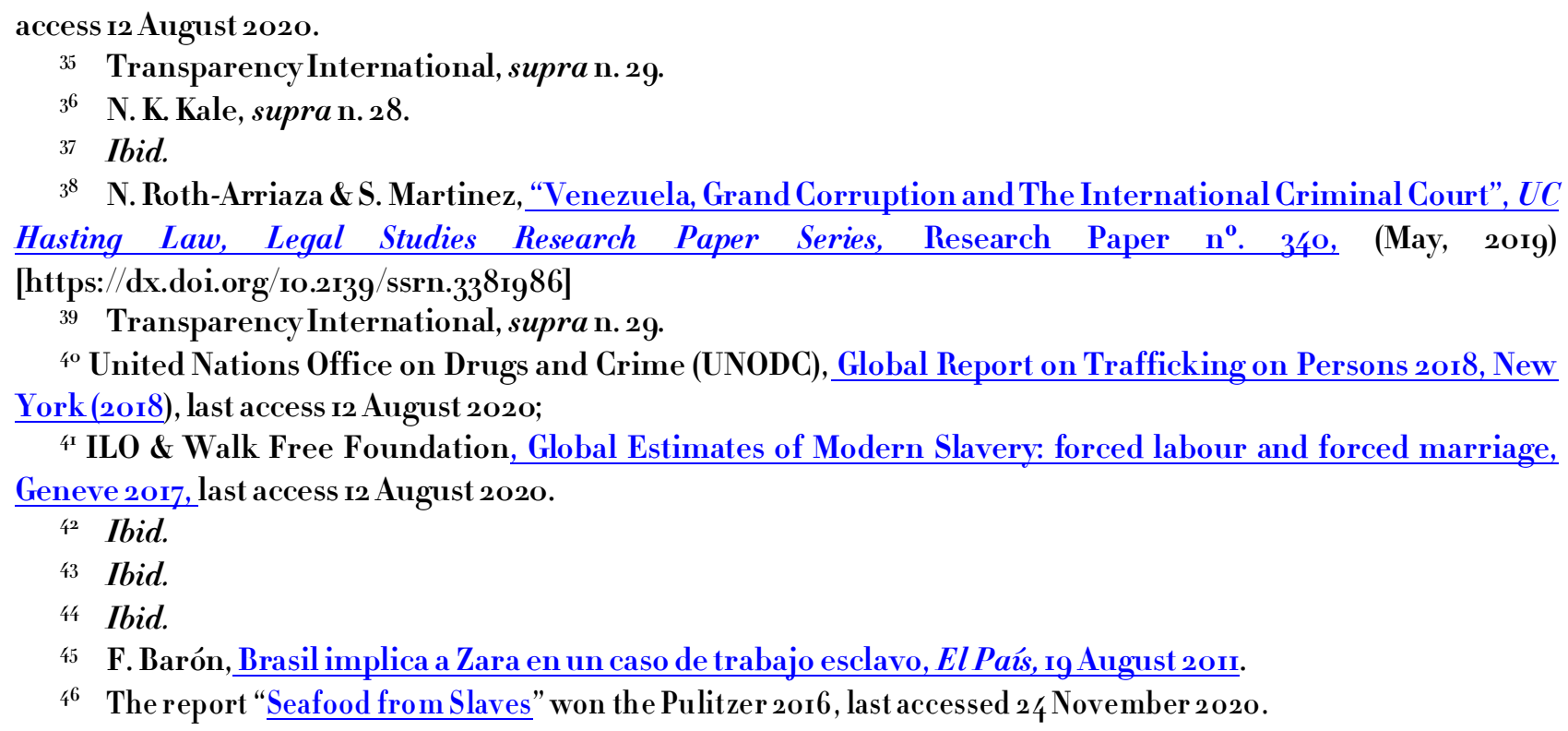

$4^{1}$ ILO \& Walk Free Foundation, Global Estimates of Modern Slavery: forced labour and forced marriage, Geneve 20I7, last access 12 August 2020. 
committed as a result of the process of economic globalization.

This same process of neoliberal globalization has favoured some normative limbo, which has helped the growth of international or transnational criminal phenomena, such as drugs and drug trafficking, money laundering, terrorism and the trafficking of people fleeing from poverty and war. According to the United Nations, the smuggling of migrants brings enormous benefits to the perpetrators of these crimes and feed corruption and organized crime. In 2org, according to the OIM, there were 9I,568 arrivals and I,O9I deaths in the Mediterranean. ${ }^{47}$ Although there has been a considerable decline since 2015 , when more than I million people fleeing war and poverty arrived on the borders of the European Union and 3,77I people died in the attempt $t^{4^{8}}$, the problematic of the immigrants crisis reflects to only the urgency to address the illegal business behind it ${ }^{49}$ but the enormous human rights crisis that leads to the concept of "necropolitics". It is understood as the public policy based on the idea that some lives do not matter. The object of this type of neoliberal policy is not kill those who do not serve but rather to let them $\operatorname{die}^{5^{\circ}}$. This concept is now starting to be used to define the policies of the European Union and its member states when they deny humanitarian treatment to displaced persons and refugees..$^{5}$

In addition, environmental abuses and catastrophes ${ }^{5^{2}}$ as a result of the development of policies of the irrational exploitation of natural resources have revealed the serious violation of human rights and collective rights of indigenous people. The case of massive pollution in the region of the northern Ecuadorian Amazon due to oil spills, a consequence of the extractive policies developed over decades by the American company Chevron - later Texaco -53 ; the case of poisoning suffered by 5 oo,ooo people in $\mathrm{I}_{9} 83$ in the region of Bhopal, India, after a leak that released gas into the atmosphere from a pesticide factory, $5^{\mathbf{I}} \%$ owned by the US company Union Carbide (part of whose assets were subsequently acquired by Dow Chemical) and $49 \%$ by the Indian government ${ }^{54}$; the case of the illegal transfer of hazardous waste to the Ivory Coast by the multinational oil company Trafigura which caused an

47 See the information here, last accessed 23 November de 2020.

$4^{8} \quad$ La OIM cuenta 3.77I muertes en el Mediterráneo en 20I5, y más de un millón de llegadas de migrantes por mar, OIM, or May 2oI6, last access I2 August 2020; UNHCR reported on 23 December 2016 in Mediterranean See Ioo people dead, bringing year total to 5, ,ooo, last accessed 23 November de 2020.

49 UNODC, “Tráfico ilícito de migrantes, 2009, last accessed 23 November de 2020.

$5^{\circ}$ C. Valverde, De la necropolítica neoliberal a la empatía radical. Violencia discreta, cuerpos excluidos y repolitización, (Icaria, $20 \mathrm{I}_{5}$ ).

$5^{\mathrm{I}} \quad$ This was argued at the meeting of the Permanent Peoples TribunaL about the violations of the human rights of migrants and refugees with impunity. It took place in Barcelona on July 7 and 8, 2oI 7 . All the information on the meeting of the Permanent Peoples Tribunal at "Update Permanent Peoples Tribunal (PPT) Session on the Violations with Impunity of the Human Rights of Migrant and Refugee Peoples”, 22 December 20 I8.

$5^{2} \quad$ Ecocide is the extensive damage to, destruction of or loss of ecosystem(s) of a given territory, whether by human agency or by other causes, to such an extent that peaceful enjoyment by the inhabitants of that territory has been or will be severely diminished. See the Ecocide Project, A. Gauger, and Pouye Rabatel-Fernel, L. Mai and Kulbicki, Louise and D. Short and P. Higgins, Ecocide is the missing $5_{\text {th }}$ crime against peace. Unspecified (Human Rights Consortium, London, School of advanced Studies, University of London, 2oI2, updatedJune 20 I3). $^{2}$

53 The class action lawsuit against Texaco-Chevron brings together 3o,ooo people gathered around the Texaco Affected Assembly. See information in Texaco/Chevron lawsuits (re Ecuador) in the Business and Human Rights Resource Center, last access I2 August 2020.

54 See information in Union Carbide / Dow lawsuit (re Bhopal) in the Business and Human Rights Resource Center, last access 12 August 2020. 
uncontrolled spill that resulted in at least I6 deaths and affected mor e than Ioo,ooo people ${ }^{55}$, are some examples of attacks on the environment committed by companies seeking profit. These attacks have serious consequences on the foundations of the physical, social, economic and cultural life of individuals and peoples, on international peace and security ${ }^{56}$, when the role of the national institutions is not always effective to the extent that there is an enormous gap between the capacity of national judicial systems to judge the crimes committed against the environment and the ability of the entities responsible for those crimes to avoid any type of control, sanction or compliance with reparation to the victims for the damages caused ${ }^{57}$.

Therefore, there are millions of people who arevictims of these serious economic abuses, which are not currently criminalized by international law because they do not fit with the traditional patterns of serious abuses attributable to the State under the exclusive exercise of political power

All the actions described in the preceding paragraphs are examples of different categories of conduct that could be considered serious economic abuse in the current system of neoliberal globalization, given that they are massive, systematic, escape the legal and jurisdictional control of States and affect fundamental values under the protection of the international community such as the human rights of individuals and peoples.

In this respect, it is possible to offer an approach to a definition of "economic crime against humanity" as the following ${ }^{5}$ :

The categories of conduct describe above may constitute an "economic crimes against humanity" when they constitute a widespread or systematic economic attack on the population:

(a) Economic crimes such as political corruption, misappropriation, unfair administration, money laundering, financial speculation in broad sectors, including such sensitive sectors as food, medicine, housing and others, which cause serious harm to society and to the foundations of economies

(b) Economic and political crimes, such as acts carried out through economic, technical-financial and major political decisions that lead to the ruin of the economic system, with devastating consequences for citizens, including structural adjustment policies or austerity policies, when they act against the interests of society and prevent States from fulfilling their international human rights obligations

55 See information in Trafigura lawsuits (re Côte d'Ivoire) en Business and Human Rights Resource Centre, last access I2 August 2020.

$5^{6}$ Yearbook of the International Law Commission, i99I, vol. II, Part 2. Report of the Commission to the General Assembly on the work of its forty-third session UN Doc. A/CN.4/SER.A/I99I/Add.l (Part 2) (hereinafter, Yearbook International Law Commission, I99I, vol. II, Part 2); ILC, Draft code of crimes against the peace and security of mankind (Part II) including the draft statute for an international criminal court. Document on crimes against the environment, prepared by Mr. Christian Tomuschat, member of the Commission Extract from the Yearbook of the International Law Commission: UN Doc. ILC (XLVIII)/DC/CRD.3, 27 March 1996 (hereinafter, Document on crimes against the environment, prepared by Mr. Christian Tomuschat I996); Yearbook of the International Law Commission, I996, vol. II, Second Part. Report of the Commission to the General Assembly on the work of its fortyeighth session. UN Doc. A/CN.4/SER.A/I996/Add.I, Part 2 (hereinafter, Yearbook of the International Law Commission, r996, vol. II, Part 2).

57 A. Nieto Martín, "Bases para un futuro Derecho internacional penal del medio ambiente", Anuario de la Facultad de Derecho de la Universidad Autónoma de Madrid (2012), at 138.

$5^{8} \quad$ L. Arenal Lora, Crímenes Económicos en Derecho internacional: propuesta de una nueva categoría de crímenes contra la humanidad (Aranzadi, 2019). 
(c) Environmental crimes and serious and permanent damage to the natural environment and, consequently, to the health of human beings and their livelihoods, when they are the result of productive, industrial or extractive activities, the development of mega-projects, the hoarding of natural resources or other acts of a similar nature, some of them in connection with armed conflicts, dictatorial regimes or complex situations of political violence.

(d) Trafficking and smuggling of persons for the purpose of exploitation, including labour exploitation, and any other form of slave labour, in particular of women and children

(e) The crimes of murder, extermination, forcible transfer, torture, rape, sexual slavery, enforced prostitution, forced pregnancy, enforced sterilization or any other form of sexual violence of comparable gravity, enforced disappearance of persons, and other inhumane acts of a similar nature, when their commission, under different forms of authorship or participation, was part of the objectives, policies or procedures connected with the pursuit of activities of an economic nature by non-State actors

(f) Other inhumane economic acts of a similar nature which create dangerous or unworthy living conditions for the population and consequently cause great suffering or seriously threaten life, physical integrity or mental/physical health, personal and organizational freedom, work, access to adequate means of subsistence, including food and housing, education, a healthy environment and natural resources such as land and water.

For the purposes of paragraph I, Economic attack means a course of conduct involving the commission of acts referred to in paragraph $I$ to a large extent, on a large scale and with an impact on all human and peoples' rights, carried out with knowledge and awareness of the consequences, and in accordance with the policy of a State or non-State organization to commit such an attack or to promote such a policy.

In conclusion, the aetiology of the "economic crimes against humanity" has to be tackled because the urgency of recognizing the importance of the economic dimension in the construction of a form of power that intervenes deeply and intensely in the lives of people. ${ }^{59}$ This economic dimension is creating new risks, threats and challenges for the international society and the international law subjected to regulating the traditional relations between States and the abuse of their political power towards their population ${ }^{60}$. However, the international law should evolve in order to respond the needs and interests of the international society in its own evolution.

\section{(C) THE RELEVANCE OF THE CATEGORY OF CRIMES AGAINST HUMANITY AS A LEGAL FRAMEWORK FOR THE}

59 Some authors intend to explain the importance of the economic dimension in the configuration of a new form of power in the contemporary society of economic globalization using the concept of geo-economics, or geopolitics of modernity. They claim this terms has come to replace traditional geopolitics, which they blamed for the crimes committed during World War II, pointing out that it had come to an end, giving way to a new form of power typical of globalization that has caused a setback in sovereignty, hier archy and political control of states over their territory in relation to other actors participating in the global market. See in J. L. Cadena Montenegro, "De la geopolítica a la geoeconomía ¿una forma virtual de colonización?, Revista CIFE: Lecturas de economía

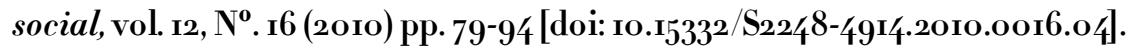

6o J. A. Carrillo Salcedo, Soberanía de Estados y Derechos Humanos en el Derecho internacional contemporáneo (Tecnos, Madrid, ı996), at 411. 


\section{REGULATION OF SERIOUS ECONOMIC CRIMES IN INTERNATIONAL LAW}

Crimes against humanity constitute the category of crimes under international law that generates the greatest interest in order to establish a regulatory framework for serious economic abuses that are under consideration in "economic crimes against humanity".

The importance and significance of this category of international crimes is unquestionable, not only from a legal perspective, but also from ethical and political one, to face the great challenges that new threats to humanity pose for international law. The positive legal regulation of crimes against humanity is one of the most valuable expressions of protection of those fundamental human values that are the object of interest to the international community.

In this sense, the category of crimes against humanity is especially important because of the rank it occupies among the norms of international law. The prohibition of these crimes is a peremptory norm of general international law or international ius cogens ${ }^{6 r}$ and its norms generate erga omnes obligations. Norms prohibiting crimes against humanity are also non-arguable nor are they subject to any statute of limitations ${ }^{6_{2}}$, their ultima ratio being to put an end to the impunity of those responsible ${ }^{63}$ and to ensure international justice for their victims ${ }^{6 / 4}$.

From crimes against humanity, it is worth highlighting their evolution. If the origins of these international crimes were linked to International Humanitarian Law (IHL) and to armed conflicts, international or non-international ${ }^{65}$, their development has affirmed the definitive disconnection from this element for the legal definition of the crimes ${ }^{66}$ moving towards the prima facie protection of fundamental universal human values, such as humanity ${ }^{67}$, international peace and human rights, both in war and peace time.

The notion of crimes against humanity has also been expanding its content and scope. The historical evolution of this category has sought to offer a legal response to acts of barbarism, due to their serious nature and consequences, not only for the effect on their direct victims, but also in the interests of all humanity; thus, charging the international community to prevent, prosecute and punish them.

6r In this vein, and despite a large discussion on this issue, the Preamble of the Draft articles on the convention on prevention and punishment of crimes against humanity states that “(...) the prohibition of crimes against humanity is a peremptory norm of general international law (jus cogens)”, supra n. Io

${ }_{2}$ M. C. Bassiouni, International Criminal Law. Sources, Subjects and Contents, vol. I, ( ${ }^{\text {rd, Martinus Nijhoff }}$ Publishers, 20o8) at I73.

$6_{3}$ M. C. Bassiouni, "Negotiatingthe Treaty of Rome on the Establishment of an International Criminal Court, Cornell International Law Journal, vol.32, Issue 3, Symposium(I999).

${ }_{64}$ Ibid.

${ }_{5}$ P. A. Fernández Sánchez (ed.) The New Challenges of Humanitarian Law in Armed Conflicts. In Honour of Professor Juan Antonio Carrillo-Salcedo, (Martinus-Nijhoff, 2005).

66 With the exception of the ICTY Statute, although in this case the connection with an armed conflict was intended to establish the jurisdiction of the Tribunal over the acts it intended to judge.

${ }^{6}$ Humanity is understood by some authors as "a value, well linked to the concept of human dignity, or, in the opinion of others, as an intrinsic quality of the human being, its intimate essence, which characterizes all human beings as political animals “ see A. GIL GIL, “Los crímenes contra la humanidad”, in A. Gil Gil and E. Maculan (dirs.), Derecho Penal Internacional, (Dikynson, 2016) at 37ı, citing Luban and his exposition on "crimes against humanness and the political animal”, in D. J. Luban, “A Theory of crimes against humanity”, Yale Journal of International Law, vol. 29 (2004), at rog et seq. 
In this regard, the substantive or material scope of crimes against humanity has undergone an expansion: increasing the number of illicit acts underlying the category, because they have responded ad hoc to behaviour revealed to be inhumane and not classified as crimes against humanity hitherto. Some examples in this sense are found in the cases of sexual violence that occurred in the conflicts of the former Yugoslavia and Rwanda ${ }^{68}$, the systematic and widespread practice of the forced disappearance of people during military dictatorships in Latin America in the 70 os and $80 \mathrm{~s}^{69}$, and the crime of apartheid..$^{\circ}$ All crimes that have been definitively incorporated into the catalogue of illegal acts of Article 7 of the RS of the ICC.

Likewise, the definition of crimes against humanity includes a residual or final clause on "other inhuman acts", present since Nuremberg, which allows a certain margin of appreciation for illegal acts of an equally serious nature and consequences to those listed previously in the Article 7 , but not strictly defined. The aim of this clause is not leaving gaps in the criminalization of egregious conduct which the vision of the legislator may not have been able to encompass. ${ }^{71}$

Besides, it is important to note the influence of International Human Rights Law in the evolution of the definition of crimes against humanity. ${ }^{72}$ The principles of humanity for the protection of the

${ }^{68}$ I. Lirola Delgado et M. Martín Martinez, Los crímenes de violencia sexual y conflictos armados (Editorial Aranzadi, Pamplona, 2017).

${ }_{69}$ See M. L. Vermeluen, Enforced Disappearance Determining State Responsibility under the International Convention for the Protection of All Persons from Enforced Disappearance (School of Human Rights Research Series, vol.5I, Utrecht University Repository, 20I2); A. A. Cançado Trindade, "Enforced Disappearances of Persons as a Violation of Jus Cogens: The Contribution of the Jurisprudence of the Inter-American Court of Human Rights", Nordic Journal of International Law , vol. 8I, Issue I (2012) 507-536 [doi: 10.II63/15718107-o8104005]; J. Sarkin, "Whythe Prohibition of Enforced Disappearancehas attained "Jus Cogens" Statusin International Law", Nordic Journal of International Law, vol. 8I, Issue 4 (2012) 537-584 [doi: 10.II63/15718107-o81040o6]; K. Ambos (coord.), Desaparición Forzada de Personas. Análisis comparado e internacional, (Deutsche Gesellschaft für] Technische Zusammenarbeit (GTZ) GmbH, Editorial Temis S. A, 2oog); J. L. Modolell González, "The crime of Forced Disappearance of Person according to the Decision of the Inter-American Court of Human Rights", International Criminal Law Review, vol. Io, Issue 4 (20Io) $475^{-4} 8_{9}$ [doi: $\left.\operatorname{Io.II}_{3} / \mathbf{I}_{57} \mathbf{I}_{1210} \mathbf{X}_{51} 8_{9} 6_{5}\right]$; F. AndreuGuzman, "The Draft International Convention on the Protection of All Persons from Forced Disappearance", Review of International Commission of Jurists, Issue on "Impunity, Crimes Against Humanity and Forced Disappearances", n.73-Io6, Geneva, September (200I).

$7^{\circ}$ P. Eden, "The Role of the Rome Statute in the Criminalization of Apartheid", Journal of International Criminal Justice, vol. I2, Issue 2, I May (20I/4) I I I-I I I [doi:Io.Iog3/jicj/mquo2/]; C. Lingaas, "The Crime against

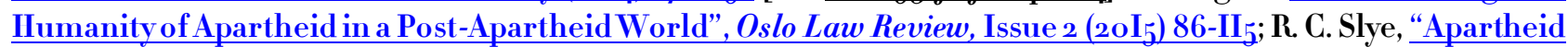
as a Crime Against Humanity: A Submission to the South African Truth and Reconciliation Commission", Michigan Journal of International Law, vol. 20, Issue 2 (I999) 273-300.

${ }_{71}$ T. Jyrkkiö, “Other Inhumane Acts' as Crimes against Humanity”, Helsinki Law Review 20I/I(20II) I83-207, at 184 [doi: 10.2139/ssrn.I 871883 ]

$7^{2}$ Schabas has pointed out "Crimes against humanity may usefully be thought of as a cognate of gross and systematic violations of human rights. Many of the definitional developments in crimes against humanity since they were first codified in the Charter of the International Military Tribunal, such as the addition of apartheid, torture, and enforced disappearance, reflect developments in human rights law. (...)The International Law Commission (ILC), which is now preparing components of a treaty on international law, once even proposed abandoning the label "crimes against humanity' in favour of 'systematic or mass violations of human rights". See W. A. Schabas, "Prevention on Crimes Against Humanity", Journal of International Criminal Justice I6 (2018), 705-728 [doi:Io.Io93/jicj/mqyo33]. See, C. Márquez Carrasco, supra n. 6, at 87. 
civilian population in war time, contained in the Martens clause ${ }^{73}$, has evolved by integrating intrinsic values into the concept of human dignity recognized by the most important international human rights treaties $^{74}$, becoming the object of supranational protection. ${ }^{75}$ Thus, the definition of these values and their protection on the basis in the prohibition of crimes against humanity has evolved in the evolution of the contemporary society threatened not only by wars, but also by other violent forms of social interaction.

This category of crimes under international law is likewise transcendental because it generates individual criminal responsibility for its perpetrators. The rules regulating crimes against humanity have included some limitations on the principle of immunity for Heads of State or official positions, on the excuse of obedience to orders from superiors ${ }^{7}$, as well as the rejection of immunities under the ICC. ${ }^{77}$ In addition, the states have an obligation to extradite or prosecute - aut dedere aut udicare - which means the State must exercise its jurisdiction to prosecute crimes fairly and effectively ${ }^{78}$ when it can't

73 E. Kwakwa, The International Law of Armed Conflitt: Personal and Material Fields of Application, (Kluver Academic, Dordrecht, I99I), at $3^{6}$. Jean Pictet interprets the concept of humanity in the sense that "(...) humanity demands that the capture be preferred to the wound, the wound to death, which, as far as possible, does not attack non-combatants, to be injured less severely - so that the injured can be operated and then healed. And in the least painful way, and that captivity is as bearable as possible in J. Pictet, "Development and Principles of International Humanitarian Law", Henry Dunant Institute, Geneva ( $\left.\mathrm{I}_{9} 8_{7}\right)$, at 74 . On the idea of humanity as the basis of the limitations of ius in bello see the work of Professor E. W. Petit De Gabriele, Las exigencias de humanidad en Derecho internacional tradicional. El marco normativo y doctrinal de la intervención de humanidad y de la asistencia humanitaria (Tecnos, 2003).

74 On the notion of human dignity as a protected legal good in crimes against humanity see R. A. Alija Fernández, La persecución como crimen contra la humanidad, (Publicacions i edicions de la Universitat de Barcelona, 20II), at 2I8-23I. On the idea of the progress of the concept of human dignity linked to the normative development of human rights, see M. C. Bassiouni, "Human rights and international Criminal justice in the twenty first Century”, M. Ishay, “Human Rights and International Criminal Justice: Looking Back to Reclaim the Future”, ), at 99-II4, and L. Wilkerson, “The Past, Present and Future of International Criminal Justice and Human Rights”, at I23-134, all of them in M. C. Bassiouni, (ed.), Globalization and its impact on the future of human rights and international criminal justice, (Intersentia Ltd, 2015);

75 M. Ollé Sesé, Justicia internacional para crímenes internacionales (La Ley, I ed. 2008), at 247-257.

$7^{6}$ C. Rueda Fernández, Delitos de Derecho Internacional. Tipificación y represión internacional (Bosch, 20oI), at 92 .

77 M. E. Reyes Milk, “El principio de inmunidad de los Jefes de Estado en actividad y su regulación en el Estatuto de Roma que crea la Corte Penal Internacional”, Agenda Internacional Año XV, N ${ }_{2}^{\circ} 6$ (20o8), at 69 -Io6.

$7^{8}$ A. Remiro Brotóns, "La persecución de los crímenes internacionales por los tribunales estatales: el principio de universalidad", in Derecho Internacional (Tirant lo Blanch, Valencia, 2007), at 494 y 495. See M. C. Bassiouni, Crimes against Humanity. Historical evolution and contemporary application, (Cambridge University Press, First paperback edition, 20II), at 27I; M. C. Bassiouni and E. M. Wise, Aut dedere aut iudicare, The duty to Extradite or Prosecute in International Law (Nijhoff, Dordrecht, I995); M. Ollé Sesé, Justicia internacional para crímenes internacionales, supra n. 66; On the relationship between the principle "aut dedere aut iudicar" and the principle of universal jurisdiction see M. Martín Martínez, “Jurisdicción Universal y Crímenes Internacionales”, University of Miami Law School Institutional Repository, vol. 9 (200I), at I84 et seq; A. Gil Gil, “Jurisdicción de los Tribunales españoles sobre genocidio, crímenes contra la humanidad y crímenes de guerra” Revista española de derecho militar, n. 87 (2006), at 55-88; A. Gil Gil, “La sentencia de la Audiencia Nacional en el caso Scilingo”, Revista electrónica de ciencia penal y criminología, no . 7, 2005; See also P. A. Fernández Sánchez, "La resistencia de los Estados a reprimir as violaciones graves de los derechos humanos” en P. A. Fernández Sánchez (coord), La Desprotección internacional de los derechos humanos (a la luz del 5 o aniversario de la Declaración Universal de los Derechos Humanos) (Universidad de Huelva, Publicaciones I988), at $4^{2}$. 
grant an extradition order. In accordance with the ILC Draft article on the prevention and punishment con the crimes against humanity the States undertake to prevent the crime, so they would accept a specific obligation in conformity with international law. ${ }^{79}$

Related to the prosecution of crimes against humanity, the States can prosecuted the responsible even invoking the principle of universal jurisdiction. This principle, based on the theory of the international nature of the offense, gives the state the power to exercise jurisdiction over a crime, regardless of nationality, territory, or any other link between the state and the criminal offence ${ }^{80}$, by virtue of each state's interest in combating crimes that all nations have condemned. ${ }^{8}$

At the same time, the ICC has a complementary jurisdiction over national ones to prosecute crimes against humanity ${ }^{8_{2}}$, except when the Prosecutor's Office acts ex officio or the Security Council has requested it. ${ }^{8_{3}}$ The complementary jurisdiction of the ICC affirms that the effectiveness of international criminal law does not have to fall on the Court, but on the firm action of the States through national regulations and their institutional capacity to prevent, investigate, extradite and/or prosecute these crimes. States must comply with obligations erga omnes because they derive from fundamental norms of international jus $\operatorname{cogens}^{8}{ }^{8}$. When the States don't exercise or are not able to exercise their jurisdiction to prosecute these crimes, the ICC may act in order to avoid the responsible go unpunished.

Because of all these legal arguments, the category of crimes against humanity would constitute an appropriate teleological and legal framework to integrate or regulate serious economic abuses in international criminal law. In this vein, Professor Bassiouni points out regarding the definition of

79 See Drafarticles, supra n. Io, art. 4. See, W. A. Schabas, supra n. 7o.

8o M. C. Bassiouni, “Introduction to International Humanitarian Law”, in Bassiouni, supra n. 53, at 280.

${ }^{8}$ I. Sánchez Legido, Jurisdicción universal penal y Derecho internacional (Tirant lo Blanch, 2oo3). On the matter of the principle of complementarity between international criminal court and national courts see $J$. T. Holmes, “Complementarity: National Courts versus the ICC”, in A. Cassese, P. Gaeta, J. R.W. D. Jones, The Rome Statute of the International Criminal Court (OxfordUniversityPress, 2oI2); M. OlléSesé, "La aplicación de Derecho penal internacional por los tribunales nacionales" in A. Gil Gil \& E. Maculan, Derecho Penal Internacional, supra n. 5 , at $\mathrm{I}_{29}$-I 5 ; M. Benzing, "The complementarity regimen of the international criminal court: international criminal justice between states soverignity and the fight against impunity", Max Planch Yearbook of United Nations Law 7 (2003) 59I-632 [doi:Io.II63/138946303775160250].

$8_{2}$ According to Sean Murphy, Special Rapporteur for Crimes against Humanity, International Law Commission, the central idea in the ILC Draft articles on prevention and punishment of crimes against humanity is "to build up national laws and national jurisdiction with respect to crimes against humanity and to place states parties in a cooperative relationship on matters such as extradition and mutual legal assistance. While the creation of international criminal courts and tribunals provides one path for punishing such crimes, a different path focuses on harnessing national institutions towards that end, so as to develop a worldwide net that provides no refuge for offenders." See in S. D. Murphy, "Foreword", Journal of International Criminal Justice I6 (2018), at. 679-682 [doi:1o.ro93/jicj/mqyo/4]

$8_{3}$ J. Alcaide Fernández, "El Principio de Complementariedad entre la Corte Penal Internacional y las Jurisdicciones Nacionales: ¿Tiempos de "Ingeniería Jurisdiccional"?" in J. A. Carrillo Salcedo, La Criminalización de la Barbarie: la Corte Penal Internacional (Consejo General del Poder Judicial, 20oo), at. $3^{8} 3^{-}$ 433; I. Lirola Delgado \& Martín Martínez, M., La Corte Penal Internacional. Justicia versus impunidad, (Ariel Derecho, 20oI), at. ${ }_{5} 6$ seq.

$8_{4}$ M. C. Bassiouni, “Crimes against Humanity: The Case for a Specialized Convention”, Washington University Global Studies Law Review, vol. 9, Issue 4, 2010, 575-593, at 592-593. See to Whitney R. Harris World Law Institute, "Iniciativa sobre Crímenes de Lesa Humanidad”, Washington University School of Law, august (2010). 
crimes against humanity "(this) has not yet settled into its final form. Its nature, scope, application, and legal elements are still somewhat unsettled" ${ }^{85}$ and this approach represents an opportunity for the identification and repression of serious economic abuses that occur on a large scale and systematically in contemporary society, constituting new forms of victimization of the population.

\section{(D) THE INCLUSION OF SERIOUS ECONOMIC ABUSES IN THE LEGAL-POSITIVE REGULATION OF CRIMES} AGAINST HUMANITY IN THE ARTICLE 7 OF THE ROME STATUTE

The possible integration of some acts that constitute economic crimes, including ecological ones, in the material scope of crimes against humanity is not a novelty. This task was part of some of the proposals studied by the ILC in the context of its work on the elaboration of the Draft code of crimes against peace and security of mankind. ${ }^{86}$

The former Special Rapporteur for this Draft Code, Mr. Doudou Thiam, proposed in the 8os some illegal activities, such as international terrorism and colonial domination, serious damage to the environment, and mercenary or economic aggression to be included in crimes against the peace and security of humankind ${ }^{87}$, and in particular into the scope of crimes against humanity. ${ }^{88}$ However, these proposals did not prosper. The ILC pointed out the Draft Code would not cover acts related to piracy, illicit drug trafficking, trafficking of women and children, slavery, among others, because the crimes considered to be part of the Code had been considered an indivisible concept, limited to those containing a political element and endangering and disrupting the maintenance of international peace and security. ${ }^{89}$

Nevertheless, the need to recognize the serious nature and consequences of the se economic abuses so-called "economic crimes against humanity" because of the significant human, social, environmental and economic damage they create for the fundamental living conditions of the population has led some judicial initiatives in international judicial instances.

${ }^{8}$ M. C. Bassiouni, "Revisiting the architecture of crimes against humanity: almost a century in the making, with gaps and ambiguities remaining - the need for a specialized convention" in L. Sadat, L., (ed.), Forging a convention for crimes against humanity (Cambridge University Press, 20II), at 43-58.

${ }^{86}$ Yearbook of the International Law Commission, 1991, vol. II, Part 2.

${ }^{8}$ Report of the International Law Commission on the work of its Thirty-fifth session, 3 May - 22 July $\left(\mathrm{I}_{9} 8_{3}\right)$, UN doc. A/38/10*, paras. 46-49; Report of the International Law Commission on the work of its Thirty-sixth session, 7 May - 27 de July (1984), paras. 52-65; Report of the International Law Commission on the work of its Thirty-seventh, 6 May - 26 July (I985), UN doc. A/40/ıO*; Yearbook of the International Law Commission, Iggr, vol. II, Part 2. Among the crimes proposed to be incorporated as crimes against the peace and security of humanity are colonial domination and other forms of foreign domination (Article I8); systematic or massive human rights violations (Article 2I); recruitment, use, financing and training of mercenaries (Article 23); Intentional and serious damage to the environment (Article 26), at 103-IO5.

${ }^{88}$ Report of the International Law Commission on the work of its Thirty-eighth session, 5 May- II July (I986), UN doc. A/4I/IO*, paras. 93-102; Report of the International Law Commission on the work of its Thirty-eighth session Forty-first session, 2 May - 2 I July (1989), UN doc. A/44/10*, paras. 1/2-210; Report of the International Law Commission on the work of its Thirty-eighth session Forty-second session, Içı May - 20 July (1990); Eighth report on the draft Code of Crimes Against the Peace and Security of Mankind by Mr. Doudou Thiam, Special Rapporteur, 8 March - 6 April (I99o), UN doc. A/GN.4/430 y Add.I.

${ }_{9}$ M. C. Bassiouni, Crimes against Humanity..., supra n. 6g, at ${ }_{17} 8$, footnote 46 . 
This has been the case of the report on the situation in Ecuador presented to the Prosecutor of the ICC in $20 I_{4}$ by the representatives of the victims of a massive pollution, which today affects more than 2 million hectares of the Ecuadorian Amazon. The legal representatives of the Texaco-Chevron company were accused of crimes against humanity of homicide, extermination, forced displacement and other inhuman acts. ${ }^{90}$ The Office of the Prosecutor did not investigate the communication because it considered that the facts were not intrinsic to the crimes subject to the material jurisdiction of the ICC. However, the purpose of the legal representatives, and of the more than 30,000 direct victims, was to attract social attention to the legal vacuum existing in international law to address these types of serious human rights violations that clash against the conscience of the humanity.

Some national judicial forums have advanced a more progressive approach related to the recognition of the importance of the connection between the development of private economic activities and the commission of crimes against humanity regulated in the RS, even equating certain economic crimes with this category of crimes under international law. In this vein, the Office of the Attorney General of Colombia announced the crime of "conspiracy to commit aggravated crime" a crime against humanity in $\mathbf{2 o I}_{7}$. The Prosecutor's Office has argued that the illegal financing of paramilitary groups by banana companies, with the purpose of achieving control of territorial and social area, as well as facilitating acts of homicide, forced displacement of civil population, forced disappearance of people, gender-based violence, illegal recruitment, torture, among other inhuman acts constitute crimes against humanity. ${ }^{91}$ In the opinion of this judicial organ, it is possible to maintain that penalizing the crime against humanity may be imposed on those businesses who voluntarily contributed to and financed armed groups outside the law -FARC, EPL, ELN and la Corriente de Renovación Socialista (CRS) in the area of the Urabá..$^{2}$

At the same time, some courts of member states of the European Union have admitted claims based on the existence of a connection between economic activities and crimes against humanity. These include the case before The Hague courts against Franz van Anraat, convicted of complicity in international crimes for supplying the Iraqi government with chemicals necessary for the production of mustard gas used in the massacres committed against the Kurdish minority in Iraq ${ }^{93}$. See also the case against Gus Kouwenhoven, convicted in $\mathbf{2 O I}_{7}$ for illicit arms trafficking and for complicity in crimes against humanity during the war in Liberia. ${ }^{94}$ Lastly, the case against the cement company

$9^{\circ}$ ICC, Communication on the situation in Ecuador presented to the Office of The Prosecutor of the International Criminal Court, March 20I5.

${ }^{9 r}$ Communication of the Office of the General Attorney of the Nation, Bogotá, 2 February 20I7, in which it was stated that in the providence issued by the Office of the Prosecutor, it is decided that the conduct that some banana entrepreneurs could incur it can be raised to the crime against humanity. The position of the in this particular case is adjusted not only to international analyses and concepts, but to the discretion by the Supreme Court of Justice, which has considered the non-applicability of statute of limitation in the concert to commit crimes when it turns out to be connected to crimes against Humanity, last access ro August 2020.

$9^{2}$ Ibid.

93 Public Prosecutor v. Frans Cornelis Adrianus van Anraat (Case No. o9/75Ioo3-04), District Court of The Hague, The Netherlands, Sentence, 23 December 2005, last access io August 2020.

${ }_{94}$ Public Prosecutor $v$. Guus Kouvenhoven (Case $N^{0}$. 220043306), Court of Appeal of The Hague, The Netherlands, Judgment, Io March 2008, last access io August 2020. 
Lafarge, which was denounced for complicity in crimes against humanity in Syria before the French courts, in 2018.95

Regardless of these incipient demonstrations of legal connectivity between economic activities and international crimes, the task of addressing the possible integration of economic abuses into the positive regulation of crimes against humanity in Article 7 of the RS implies a great legal challenge. So, the conducts that are economic abuses should be carried out in a context of gravity similar to crimes against humanity, meaning "as a part of a widespread or systematic attack directed against any civilian population, with knowledge of the attack [...] pursuant to or in furtherance of a state or organizational policy to commit such attack".

(I) An expansive approach to the notion of "attack against the civilian population" for economic crimes against humanity"

The history of the evolution of the legal definition of crimes against humanity, influenced by the development of jurisprudence and the contributions of doctrine, has well established that the "generalized and systematic attack against the civilian population" constitutes the context for the legal classification of certain illegal acts as crimes against humanity.

The notion of "attack" according to Article 7 (II) (a) of the RS consists of a "the multiple commission of acts referred to in paragraph I against any civilian population, pursuant to or in furtherance of a State or organizational policy to commit such attack".

In the RS, according to Alija Fernández's opinion, the notion of attack is defined restrictively and ambiguously. On one hand, the relevant acts of violence would be limited to those listed in Article 7 as crimes against humanity. On the other hand, it seems to require the multiple commission of these acts to be in the presence of an attack. ${ }^{96}$ Therefore, the notion of attack generally accepted indicates that its content and description is the very realization of the illegal acts of Article 7 , with a total equivalence between the attack and the criminal acts that shape the contours of the general aggression.

However, the legal definition of crimes against humanity, according to customary international law, is today disconnected from armed conflicts ${ }^{97}$-the attack doesn't need to be a military attack ${ }^{9}$ —or acts of a strictly violent nature ${ }^{99}$. This allows us to move towards a broader definition of the notion of attack against the civilian population based on behaviour or illegal acts other than those listed in Article 7 of the RS.

In this vein, the actions integrating the so-called "economic crimes against humanity", such as political corruption, serious, extensive and long-term or permanent damage to the environment,

95 Information on Lafarge lawsuit (re complicity in crimes against humanity in Syria), last access Io August 2020.

$9^{6}$ A. R. Alija Fernández, supra n. $6_{5}$, at 254 .

97 A. Cassese, International Criminal Law, Oxford University Press, Second Edition, 20o8, at 99.

$9^{8}$ M. C. Bassiouni, Crimes Against Humanity..., supra n. 69, at. 365 .

99 Imposing an apartheid system or exerting pressure on the population to act in a certain way may enter the scope of an attack. See ICTR-96-3, The Prosecutor $v$. Rutaganda, Judgment and Sentence, 6 December I999, para. 7o: "An attack may also be non-violent in nature, like imposing a system of apartheid, which is declared a crime against humanity in Article I of the Apartheid Convention of I973, or exerting pressure on the population to act in a particular manner may also come under the purview of an attack, if orchestrated on a massive scale or in a systematic manner". 
human trafficking, economic-political decisions, such as adjustment or austerity policies, among others, can be considered a form of "economic attack" on the civilian population, when they are systematic or generalized, the result of the policy of a state or non-state organization, and when they are carried out with knowledge of the attack, creating a situation of sufficient gravity to be considered by international criminal law.

The fact of separating the idea of the of attack from the multiple commission of illegal acts established in Article 7 (I) of the RS, would contribute to breaking the supposed circularity of its definition. In fact, the proposal of separate the underlying acts of crimes against humanity from the idea of the attack is a possibility that the international jurisprudence has already recognized. The British Court of the occupied zone, after World War II, in application of the Law of the Control Council No. Io in the Strafsache $78 / 48$ case, considered a form of attack "the despotic domain of violence of the Nazis", in addition to the destruction of a cultural asset -the synagogue - that constituted conduct sufficiently connected with the attack on charges of a crime against humanity. ${ }^{100}$ The ICC has recently made some consideration in this regard, since in the Katanga case it has declared the need to consider the attack, the rating of the attack and the underlying acts in separate steps. ${ }^{\text {Ior }}$ Likewise, the Program of the European Union for Social Cohesion in Latin America, has referred to corruption as a way to "attack" the civilian population in the following terms:

"Corruption also threatens society, affecting the moral order and trust; it directly harms a significant number of people receiving public services or benefits, affecting the most vulnerable sectors of society deprived of essential conditions such as health, education, housing, work, employment security and justice. This promotes the increase in poverty and exclusion due to diversion of resources and hinders the implementation of public policies that ensure social and cultural economic rights". ${ }^{\text {o2 }}$

A more contemporary interpretation of the definition of the term "attack against the population", from the perspective of the study of economic crimes, also suggests a critical approach to the meaning of the term "against." According to the jurisprudence of the international criminal courts, in particular the International Criminal Tribunal for the former Yugoslavia (ICTY) and the ICC, the word "against" indicates that a civilian population is the main target of the attack, rather than an incidental victim ${ }^{\mathrm{io}}$, also pointing out that the term refers to the intention and not to the physical outcome of the acts. ${ }^{104}$ When we are talking about "economic crimes against humanity" as attacks of an economic nature -including environmental ones - the victims of these actions are not casual or circumstantial to them because the harm on the civil population is the result of the natural position that they occupy in the

${ }^{100}$ See in E. Schmidt, Taking economic, social and cultural rights seriously in international criminal law (Cambridge University Press, 20I 5 ), at. 93, footnote 9o.

${ }^{\circ}$ ICC-oI/o4-oI/o7, Situation in the Democratic Republic of the Congo in the case of the Prosecutor v. Germain Katanga, Judgment pursuant to Article 74 of the Statute, 7 March 201‘, paras. Iog6-ıo99.

${ }^{102}$ Ibid.

${ }^{103}$ IT-96-23-T\& IT-96-23/I-T, The Prosecutor v. Dragoljub Kunarac Radomir Kovac and Zoran Vukovic, Judgement, 22 February 2ooI(hereinafter, Kunarac case 2001).

${ }_{104}$ ICG-or/o5-oI/o8, Decision Pursuant to Article 6I(7)(a) and (b) of the Rome Statute on the Charges of the Prosecutor Against Jean-Pierre Bemba Gombo, I5 June 2009 (hereinafter, Bemba case 20o9) paras. 76 and 94; ICGoI/o9-9, Decision Pursuant to Article I5 of the Rome Statute on the Authorization of an Investigation into the Situation in the Republic of Kenya, 3 I March 2010, para. 82; ICC-0I/04-02/o6, Situation in the Democratic Republic of the Congo in the case of the Prosecutorv. Bosco Ntaganda, Decision on the Prosecutor's Application under Article $5^{8,}$, 2 July 2012 , paras. 20 and $2 \mathrm{I}$. 
context in which economic abuses are committed. This means that in some cases the victims are the main objectives of these economic abuses -i.e. the crime of human trafficking which has as its purpose victimizing people to obtain a benefit- and in other cases when victims are indirect targets as a result of the externalities of policies behind these abuses of economic nature - i.e. the crime of corruption and the deaths that occur accordingly among vulnerable populations as a result of the illicit diversion of public funds.

Therefore, it is suggested to employ the expression "attack on the civilian population" because it would mean the victims were an inherent consequence to the development of the economic crimes causing damage or destruction, not only or strictly a direct target.

The use of the expression "attack on the civilian population" allows us to address the question of the intention and knowledge of the attack from a risk-oriented approach. In this sense, the Draft Code of crimes against peace and security of humanity of I $99 \mathrm{I}$ proposing the incorporation of "intentional and serious damage to the environment" seems to illuminate this approach to the mental element.

This Draft Code would sanction "those who intentionally cause or instigate the cause of serious, long-term and widespread damage to the environment". ${ }^{105}$ Although the essential element of the definition of crime was provided by the adverb intentionally, which referred to the express or specific purpose of causing the damage, some members of the ILC judged the following: if the deliberate violation of certain regulations related to the protection of the environment was carried out for other reasons - i.e. for profit - and caused extensive, long-term and serious damage then this would constitute a crime against humanity regardless of whether the purpose had been or not been to cause damage. This particular opinion of some members of the ILC was intended to reconcile the apparent contradiction between Article 26 and Article 22 on the war crimes of the Draft Code, which also dealt with the protection of the environment. According to Article 22, a war crime was not only the use of methods or means of war that would have been conceived to cause damage, but also that of those who were expected to cause damage, even when the purpose of using those methods or means would not have been explicitly to cause damage to the environment. ${ }^{106}$

Translating this idea to the field of human, social, economic and environmental damage caused by the commission of serious economic abuses, it could be affirmed that, although carrying out practices and using methods or means that have not yet been conceived to cause specific damage to a civil population, they can be foreseen. Thus, the intention does not exclude the possible classification of those acts as crimes against humanity.

The notion of attack, in line with this interpretation, could be detached definitively from its etymological origin, which emanates from the Italian word attaccare and which can be translated as "start a fight" and linked to a violent or impetuous act carried out with the express purpose of harming, destroying or defeating someone or something. Therefore, we could move towards a new dimension of the concept of attack that would encompass abuses of an economic nature undertaken principally to obtain a profit, benefit or maintain a position or balance of political-economic power, however, not with the express purpose of doing harm. Although these forms of economic abuses are indirect, even

${ }^{105}$ Draft Code of crimes against peace and security of mankind, Art. 26, in Yearbook of the International Law Commission, i99I, vol. II, Part 2.

ıo6 Ibid, comment 6, at II6. 
structural, they may have a violent effect on a civil population which can be harmed, damaged or destroyed.

According to the above, even though the definition of attack connected with armed conflicts, or with acts of direct violence, finds a very solid basis in international law, a strict interpretation of this term based exclusively on the commission of acts listed in the RS, does not fully correspond to a broader protective function underlying the prohibition of crimes against humanity ${ }^{107}$. The actions, forms and means used to attack the population can today be expressed in a diverse manner and do not necessarily require the use of armed force or physical violence to end life or hurt someone directly or indirectly ${ }^{108}$. Instead, it can be carried out through serious economic abuses that are not part of the current catalogue of conduct that constitute crimes against humanity.

A reformulation of the definition of the expression "attack against the civilian population" for the legal definition of crimes against humanity in Article 7 of the RS would allow the creation of a way to prosecute serious abuses committed on populations based on behaviour of an economic nature before the ICC. The acceptance of a new dimension of the concept of attack would allow admitting international crimes of murder, forced displacement, extermination, slavery, rape and submission to other inhuman acts when they are committed in contexts of violence other than war, such as circumstances of instability or political violence. These crimes could be qualified as international crimes under the jurisdiction of the ICC when they are a consequence of generalized or systematic practices including but not limited to corruption, economic-political crimes, illicit and serious human damage to the environment; thus becoming an economic attack on civilian populations.

Definitely, the recognition in international law of a new dimension of the concept of attack under the chapeau-clause of crimes against humanity, such as "economic attack", is central to establishing a solid connection between crimes against humanity and the so-called "economic crimes against humanity."

(2) A re-conceptualization of the policy element the organizations behind politics in the

\section{Rome Statute}

Regardless of whether the policy element in crimes against humanity is a procedural or jurisdictional element or if it meets both criteria, or is an additional matter to the above ${ }^{109}$, what seems to be affirmed is that the existence of the element of policy confers substance on the connection among the illegal acts. Furthermore, the policy element contributes to the understanding of the concept of attack and confirms that behind it there is some form of organizational authority, with capacity to commit crimes against humanity, moving away from the idea that these are actions attributable to individual and spontaneous behaviour, which would be otherwise outside the jurisdiction of the ICC. ${ }^{\text {Io }}$

When we think on "economic crimes against humanity", and on how to interpret the policy element from the definition contained in the RS, two questions arise. First, if the RS points out in Article 7(II)(a)

${ }^{10} 7$ E. Schmidt, supra n. 89 , at 77 and 78 .

${ }_{10}$ Ibid, at 77. The author notes that violence can be understood more broadly, going beyond the direct violence inflicted through weapons, machetes or physical force.

'09 C. Márquez Carrasco, "Los elementos comunes de los crímenes de lesa humanidad”, Revista General de Derecho Penal 9, (2008), at $3^{2}$.

по Ibid, at 5 o. 
that the attack must be “(...) in accordance with the policy of a state or an organization to commit that attack or to promote that policy" "': does it mean the policy element must be exclusively from the state and the organizations within its structure, but also from other non-state organizations? Second question arises if the answer to the first question is affirmative: what should be the characteristics of the policy element attributable to those non-state actors?

Before analysing the question of the policy for "economic crimes against humanity", we will proceed to a preliminary examination of the actors behind this policy. Which actors responsible to serious economic abuses could be integrated into the definition of the term organization of Article 7 (II)(a) of the RS.

Some of the entities responsible for the commission of the so-called "economic crimes against humanity" are clearly state-like and they can be identified without too many obstacles. When they act it is possible to isolate a state policy behind the crimes -i.e., the highest authorities of the state might hold a policy of illicit use of public resources for their own benefit, through an institutionalized system of corruption, resulting in death among the population by starvation by not financing food programs-.

However, other actors responsible of serious economic abuses are non-state in nature. We are talking particularly about private actors whose principal aim is to make profits because of their economic activities. It would be worthwhile to interpret a new concept of the policy element for these actors in parallel to the concept of the state policy -i.e., a multinational company due to following of an austerity policy in investment causes serious, extensive and long-tern damage to the environment, thereby seriously undermining the integrity and physical health of the population; also, an international criminal group that carries out a systematic practice related to human trafficking for labour exploitation-.

Next, we will proceed to analyse the possible inclusion of non-state actors acting by economic motivation within the concept of Article 7 (II) of the RS, based on some decisions adopted by the IIC that may shed some light on this issue.

The Decision authorizing an investigation into the situation in Kenya $20{ }^{\prime \prime 2}{ }^{H 2}$ has particularly addressed this question of how the term "organization" should be interpreted in the definition of crimes against humanity after the post-electoral violence carried out by the criminal acts of some eminent political representatives of the "Orange" Democratic Movement, media representatives, former members of the Kenyan police and army, kalenyin elders, local leaders, and criminal organization Mungiki. ${ }^{13}$ In this decision, most of the judges of the Chamber expressly rejected the idea that "only organizations similar to the states" could be considered as organizations for the purposes of

III Italics ours.

"2 ICC-o I/o9-9,Decision Pursuant to Article I5 of the Rome Statute on the Authorization of an Investigation into the Situation in the Republic of Kenya, $3^{\mathrm{I}}$ March 20I0, para. 90.

"13 This decision was followed in ICC-OI/o9-0I/II, Situation on the Republic of Kenya in the case of the Prosecutor v. William Samoei Ruto, Henry Kiprono Kosgey and Joshua Arap Sang. Decision on the Prosecutor's Application for Summons to Appear for William Samoei Ruto, Henry Kiprono Kosgey and Joshua Arap Sang, 8 march $201 \mathrm{I}$ (hereinafter, Ruto case $201 \mathrm{I})$; too ICC-OI/o9-0I/II, Situation on the Republic of Kenya in the case of the Prosecutor $v$. William Samoei Ruto, Henry Kiprono Kosgey and Joshua Arap Sang. Decision on the Confirmation of Charges Pursuant to Article 6I(7) (a) and (b) of the Rome Statute, 23 January 2oI2. The case against Ruto and Sang ended in $20 I 6$ through the acquittal of those caused. The document is not yet available on the page of the International Criminal Court. It can be seen, however, in “case information sheet”, electronically available. 
Article 7 (II)(a). ${ }^{11 /}$ This thesis has been subsequently confirmed in the Kenyatta, Muthaura and Hussein AliAppeal Request Decision of $20 \mathrm{II}^{\mathrm{I5}}$ and in the Decision confirming charges against Kenyatta, Muthaura and Hussein Ali of $20 \mathrm{I}^{116}$. This is of great relevance in light of this study.

\section{(a) The concept of "organization" in the Rome Statute and its applicability to non-state actors in "economic crimes against humanity"}

The possibility that other actors other than the State to commit crimes against humanity does not mean minimizing its role in in ternational law neither degrade the category of this category of international crimes.

The Article 7 of RS of the ICC, in the extend that defines crimes against humanity as those committed "pursuant to or in furtherance of a State or organizational policy to commit such attack" would lead to reflect on the question of whether the integration of the term "organization" in the Statute would allow extending its material scope to organizations that are not exclusively criminal organizations into the State apparatus or state-like organizations. ${ }^{.18}$

In order to initiate this task regarding the study of the inclusion of the expression "organization" in the RS, it has been considered appropriate to make a brief reference to the expression "criminal organization" used in the Nuremberg trials to deal with the massive, organized, voluntary and intentional criminality the Nazi government. ${ }^{19}$

In Nuremberg, this form of mass criminality was understood as a new phenomenon. A large number of perpetrators had participated and produced a huge number of victims and this circumstance required new procedures to ensure that war criminals did not escape from punishment by reason of the enormous material and procedural difficulties that would arise to prove their individual responsibility. ${ }^{120}$

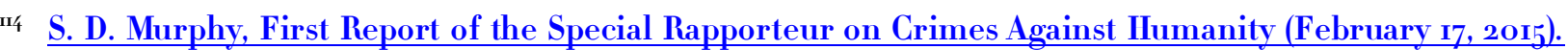
United Nations International Law Commission, A/CN.4/680; GWU Legal Studies Research Paper No. 20I5-I2; GWU Law School Public Law Research Paper No. 20I5-12, at 79-80.

${ }^{{ }_{5} 5}$ ICC-oI/o9-02/II, Situation in the Republic of Kenya, Decision on the Prosecutor's Application for Summonses to Appear for Francis Kirimi Muthaura, Uhuru Muigai Kenyatta and Mohammed Hussein Ali, 8 March 20 II.

${ }_{116}$ ICC-oI/o9-02/II, Situation in the Republic of Kenya, Decision on the Confirmation of Charges Pursuant to Article 6I (7) (a) and (b) of the Rome Statute, 23 January 2012 The ICC has closed the case against Kenyatta due to lack of evidence. See ICC-oI / $09-02$ / II-IOO 5 , Decision on the withdrawal of charges against Mr Kenyatta, $\mathrm{I}_{3}$ March 2015.

${ }_{\text {"17 }}$ RS, Article 7(II)(a) expressly states that: "Attack against a civilian population" means a course of conduct involving the multiple commission of acts referred to in paragraph $\mathrm{r}$ against any civilian population, pursuant to or in furtherance of a State or organizational policy to commit such attack;(...)"

"18 In this sense the opinions of Schabas and Bassiouni in M.C. Bassiouni, Crimes Against Humanity..., supra n. 69; W. Schabas, The International Criminal Court, (Oxford; OUP, 2oIo)

"19 R. Arens, "Nuremberg and Group Prosecution”, Washington University Law Review, vol. 195I, issue 3 (195I), 329-357; D. Fraser, "(De) Constructing the Nazi state: Criminal Organizations and the Constitutional Theory and of the International Military Tribunal," 32 Loyola of Los Angeles International and Comparative Law Review (20I7) $\underline{\text { II } 7-I 86}$, at I3I; N. Jørgensen, "A Reappraisal of the Abandoned Nuremberg Concept of Criminal Organizations in the Context of Justice in Rwanda," Criminal Law Forum, vol. I2, Issue 3, 371-406 (200I) [doi:Io.IO23/A:I014980232159].

${ }^{120}$ N. Jørgensen, supra n. Io6, at 393. 
The United Nations Commission on War Crimes, in order to avoid this circumstance, proposed through the Subcommittee possible solutions, among them, that the subjects involved in those crimes of aberrant nature could be held individually responsible on the basis of their voluntary membership in an organization declared criminal. ${ }^{\text {I2 }}$

The Nuremberg Statute, on the basis of these recommendations, in its Articles from 9 to II, instituted of power to the Military Criminal Court to declare that a group was a criminal organization. This meant that in subsequent proceedings the criminal nature of the group could not be questioned, and an individual could suffer punishment for the crime of belonging to that organization, in addition to other possible punishments for their participation in the criminal activities of said organizations. ${ }^{122}$

Although the Statute of the Nuremberg Tribunal made no reference to the definition of the term criminal organization, six groups of organizations were charged by prosecutors from the United states, France, Britain and the Soviet Union: the Cabinet of the Nazi Government (Reichkabinett), the Senior Management of the Nazi Party (Leadership Corp of the Nazi Party, the SS, the Gestapo, the SA and the General Staff and Senior Officers of the German Armed Forces (General Staff and High Command of the German Armed Forces). ${ }^{23}$

According to the characteristics presented by these accused organizations, Justin Jackson, who was Chief Prosecutor during the main trial within the Nuremberg Proceedings, declared that the collective criminality of those organizations rested on five essential features:

i) The group or organization be "a group of associated persons in an identifiable relationship with a collective or general purpose" or with "common action plan";

ii) The membership in the group "must be generally voluntary";

iii) "The purpose of the organization must be criminal", in the sense of the crimes contained in the Nuremberg Statute referring to crimes against peace, war crimes and crimes against humanity;

${ }_{221}$ This was the proposal presented by France in 1945 , in accordance with the provisions of Articles $256-267$ of the French Criminal Code, in the Subcommittee created by the United Nations Commission on War Crimes. See in N. Jørgensen, supra n.ıo6, at 388.

${ }_{122}$ The Nuremberg Statute referred to these issues in Articles 9, 10 and $\mathrm{II}$ in the following terms:

Article 9: "At the trial of any individual member of any group or organization the Tribunal may declare (in connection with any act of which the individual may be convicted) that the group or organization of which the individual was a member was a criminal organization. After receipt of the Indictment the Tribunal shall give such notice as it thinks fit that the prosecution intends to ask the Tribunal to make such declaration and any member of the organization will be entitled to apply to the Tribunal for leave to be heard by the Tribunal upon the question of the criminal character of the organization. The Tribunal shall have the power to allow or reject the application. If the application is allowed, the Tribunal may direct in what manner the applicants shall be represented and heard."

Article Io: "In cases where a group or organization is declared criminal by the Tribunal, the competent national authority of any Signatory shall have the right to bring individuals to trial for membership therein before national, military or occupation courts. In any case the criminal nature of the group or organization is considered proved and shall not be questioned. "

Article II: "Any person convicted by the Tribunal may be charged before a national, military or occupation court, referred to in Article Io of this Charter, with a crime other than of membership in a criminal group or organization and such court may, after convicting him, impose upon him punishment independent of and additional to the punishment imposed by the Tribunal for participation in the criminal activities of such group or organization."

${ }^{123}$ D. Fraser, supra n. 1o8, at I3I. Also, in Jørgensen, supra n. Io6, at 389 and $39^{\circ}$. 
iv) "The criminal objectives or methods of the organization must be of such character that their members can in general be correctly accused of their knowledge”;

v) "Some individuals accused must have been a member of the organization and must be convicted of any act, on the basis that those organizations have been declared criminals". ${ }^{24}$

The Military Criminal Court provided a definition of criminal group or organization as follows ${ }^{125}$ :

"A criminal organization is analogous to a criminal conspiracy in that the essence of both is co-operation for criminal purposes. There must be a group bound together and organized for a common purpose. The group must be formed or used in connection with the commission of crimes denounced by the Charter. Since the declaration with respect to the organizations and groups will, as has been pointed out, fix the criminality of its members, that definition should exclude persons who had no knowledge of the criminal purposes or acts of the organization and those who were drafted by the state for membership, unless they were personally implied in the commission of acts declared criminal by Article 6 of the Charter as members of the organization. Membership alone is not enough to come within the scope of these declarations".

Nuremberg's lesson was that in order to effectively address the issue of the responsibility of a multitude of perpetrators, who had participated in countless aberrant crimes, and who had left an alarming number of victims, it was necessary to establish new procedures to avoid impunity, being that for this the concept of criminal organization, and the scheme of individual criminal responsibility on the basis of belonging to a qualified criminal organization, was designed as a method to deal with this type of mass criminality. ${ }^{126}$

The United Nations General Assembly, through resolution 95 (I), iI December $1946^{127}$, affirmed the principles of international law recognized in the Statute and in the judgments of the Nuremberg Tribunal. The ILC adopted a formulation of those principles in the year $I_{95} \mathrm{o}^{\mathrm{I2} 8}$ giving the concept of criminal organization a place in international law. However, it has not been invoked or subsequently developed $^{129}$ despite the fact that extraordinary events of violence developed in a framework of macro criminality have occurred later. ${ }^{130}$

The Plenipotentiary Conference, held in Rome for the creation of the ICC, neither allow to prosper the idea of including legally defined (criminal) organizations within the framework of the RS in line with the precedent of the organizations contemplated at Nuremberg, once the proposal submitted by France of Article 23 on criminal liability of legal persons was rejected. ${ }^{13 \mathrm{r}}$

${ }_{124}$ UNWCC, History of the United Nations War Crimes Commission and the Development of the laws of the war, (I948), at $3 \mathbf{0}_{5}$.

${ }^{125}$ IMT, Trial of the major war criminals before the IMT, Nuremberg, I4 November 1945 - I October 1946 (Published At Nuremberg, Germany 1947) Volume I, Official Text in the English Language Official Documents, at. $25^{6}$.

${ }^{126}$ See R. Arens supra n.ıо8, at 329-357; F. Fraser, supra n. 1o8; N. Jorgensen, supra n. Io6.

${ }^{127}$ GA, Res. 95 (I), II December I946, "Confirmation of the Principles of International Law recognized in Nuremberg".

${ }^{128}$ Yearbook of the International Law Commission, $195^{\circ}$, vol. II. Documents of the second session including the report of the Commission to the General Assembly. UN doc. A/CN. $4 /$ SER.A/I95o/Add. I, 6 June I957. Principles of International Law Recognized in the Charter of the NürnbergTribunal and in the Judgment of the Tribunal, with commentaries, at 374 and seq.

${ }^{129}$ Jørgensen, supra n. 1o6, at. 397.

${ }^{\text {r3o }}$ See the conflict in Rwanda and the criminal acts carried out by the Interahamwe.

${ }^{\mathrm{r}}{ }^{\mathrm{r}}$ United Nations Diplomatic Conference of Plenipotentiaries on the Establishment of an International Criminal Court Rome, I 5 June -I 7 July I998. Official Records Volume II Summary records of the plenary 
Although the negotiations for the adoption of the RS could be considered a failure for not having included the idea of legal persons -organizations or groups- as responsible for crimes against humanity, the instrument incorporated the term "organization" in the Article 7 (II) when referring to the fact that the crimes will be "pursuant to or in furtherance of a State or organizational policy to commit such attack". However, the concept of organization was defined neither by the RS nor the document of the Elements of Crimes leaving unclear what kind of entity could be integrated into this expression. For this reason, the ICC is expected to play an important role in this matter, its jurisprudence specifying the content of this expression.

In this respect, it must be said that it has been some relatively recent decisions of the ICC that have shed some light on the scope of the term organization, showing a position of some flexibility or openness to the possible extension of its definition of different types of organizations, including private groups such as companies or international criminal groups as typical actors of "economic crimes against humanity".

The Pre-Trial Chamber II of the ICC in the Decision on the authorization of the investigation on the post-electoral situation in Kenya $20 I o^{13^{2}}$ has particularly addressed this question of how the term "organization" should be interpreted in the definition of crimes against humanity. Also, the Decision has stated the criteria that must be met for an entity or group to be included within the concept of organization of Article 7 of the RS in what is called the "capacity test". These criteria have been subsequently confirmed in the Appeal Decision for Francis Kirimi Muthaura, Uhuru Muigai Kenyatta and Mohammed Hussein Ali of $2 \mathrm{OII}^{133}$, in the Decision confirming charges against Kenyatta, Muthara and Hussein Ali of $2 \mathrm{OI}_{2}{ }^{134}$, as well as in the Decision confirming charges against Ruto and Sang of $20 \mathrm{I}_{2} .^{\mathrm{I} 35}$

In the Authorization Decision of an investigation on Kenya in 2oIo , the majority of the Pre-Trial Chamber II confirmed that the decisive element for the definition of an organization within the meaning of Article 7 of the RS was that the group had the capacity to carry out acts that violate basic human values ${ }^{13}{ }^{6}$, also proposing a schema of non-exhaustive criteria or factors that would help

meetings and of the meetings of the Committee of the Whole. UN Doc. A / CONF.I8 3 /SR i to 9 (Vol. II). Proposal submitted by France UN Doc. A/CONF. I 8 3/C. I/L.3).

Art. 23: (criminal organizations): " 5 . when the crime was committed by a natural person on behalf or with the assent of a group or organization of everykind, the Court maydeclare that this group or organization is a criminal organization. 6 . In the cases where a group or organization is declared criminal by the Court, this group or organization shall incur the penalties referred to in Article 76 , and the relevant provisions of Articles 73 and 79 are applicable. In any such case, the criminal nature of the group or organization is consider ed proved and shall not be questioned, and the competent national authorities of any state party shall take the necessary measures to ensure that the judgement of the Court shall have binding force and to implement it".

${ }^{{ }_{3} 2}$ ICC-or/o9-9, Decision Pursuant to Article $I_{5}$ of the Rome Statute on the Authorization of an Investigation into the Situation in the Republic of Kenya, 3 I March 2010.

${ }^{1} 33$ ICC-oI/o9-02/II, Situation in the Republic of Kenya, Decision on the Prosecutor's Application for Summonses to Appear for Francis Kirimi Muthaura, Uhuru Muigai Kenyatta and Mohammed Hussein Ali, 8 March 2011.

${ }_{134}$ ICC-oI/o9-02/II, Situation in the Republic of Kenya in the Case of the Prosecutorv. Francis Kirimi Muthaura, Uhuru Muigai Kenyatta and Mohammed Hussein Ali. Decision on the Confirmation of Charges Pursuant to Article $6 \mathrm{I}$ (7) (a) and (b) of the Rome Statute, 23 January 2012.

${ }^{335}$ ICC-oI/og-oI/II, Situation on the Republic of Kenya in the case of the Prosecutor $v$. William Samoei Ruto, Henry Kiprono Kosgey and Joshua Arap Sang. Decision on the Confirmation of Charges Pursuant to Article 6r(7) (a) and (b) of the Rome Statute, 23 January 2012.

${ }^{13}{ }^{6}$ Ibid, para 93. 
determine said ability to act, without these being a rigid legal definition in themselves; nor was it required that all these elements should be fully satisfied. ${ }^{137}$

These criteria established by Pre-Trial Chamber II of the ICC to define which entity should be integrated in the definition and scope of the concept of organization within the RS, can be summarized as follows ${ }^{13^{8}}$ :

i) the group is under a responsible command, or has an established hierarchy;

ii) the group possesses, in fact, the means to carry out a widespread or systematic attack against a civilian population;

iii) the group exercises control over part of the territory of a State;

iv) the group has criminal activities against the civilian population as a primary purpose;

v) the group articulates, explicitly or implicitly, an intention to attack a civilian population;

vi) whether the group is part of a larger group, which fulfils some or all of the above mentioned criteria.

Pre-Trial Chamber II understood that according to these criteria there were sufficient grounds to investigate whether post-electoral violence in Kenya, which appeared to have been planned and organized in advance by an association or network of authors composed by political representatives of the Democratic Movement 'Orange', representatives of the media, former members of the Kenyan police and army, Kalenyin elders, other local leaders and the Mungiki criminal organization, a sympathizer of the National Unity Party. All these acts of violence seem to result in the commission of crimes that fell within the scope of the ratione materiae of the ICC. ${ }^{139}$

The majority of the judges of this Chamber, in the different decisions on the situation of violence in Kenya, expressed that they considered Mungiki organization ${ }^{1 / 4^{\circ}}$ a criminal organization. ${ }^{1 / 4}$ This organization met the requirements to be integrated into the definition and scope of the concept of organization under the RS because it operated as a hierarchical, vast and complex structure with a clear internal division, and its members subject to obedience to internal rules. It also carried out military training tasks, in order to carry out violent operations, including executions. In addition, Mungiki exercised control over fundamental aspects of social life in the poorest residential areas, which included basic services such as electricity, water, sanitation, and a community justice system,

${ }^{137}$ ICC-oI/o9-9,Decision Pursuant to Article I5 of the Rome Statute on the Authorization of an Investigation into the Situation in the Republic of Kenya, 3I March 2oro, para. 93: "it is important to clarify that, while these considerations may assist the Chamber in its determination, they do not constitute a rigid legal definition, and do not need to be exhaustively fulfilled.”

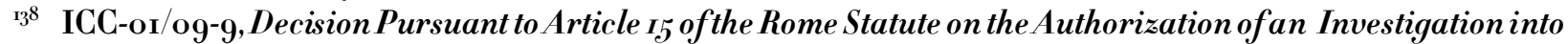
the Situation in the Republic of Kenya, 3 I March 2oIo, para. 93; ICC-oI/o9-oI/II, Situation on the Republic of Kenya in the case of the Prosecutor $v$. William Samoei Ruto, Henry Kiprono Kosgey and Joshua Arap Sang. Decision on the Confirmation of Charges Pursuant to Article 6r(7)(a) and (b) of the Rome Statute, 23 January 20I2, para. I85; correction of the Decision under Article $I_{5}$ of the Rome Statute concerning the authorization of an investigation into the situation in the Republic of Côte d'Ivoire, ICC-O2 / II-I/4-Corr., paras. 45 and 46, October 3, $20 \mathrm{II}$.

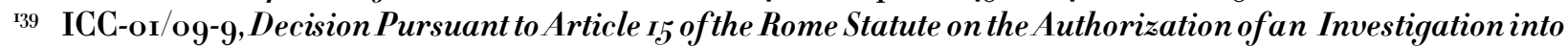

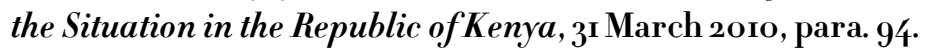

${ }_{1} 4^{\circ}$ ICC-or/o9-02/II, Situation in the Republic of Kenya, Decision on the Confirmation of Charges Pursuant to Article $6 I$ (7) (a) and (b) of the Rome Statute, 23 January 2012.

ı'i Ibidem, para. 206. 
also having control over transport and business, as well as charging taxes and fees, among other illicit

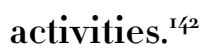

However, these decisions regarding the situation on Kenya were not taken unanimously by all the judged of the Pre-Trial Chamber II. Judge Hans-Peter Kaul showed dissenting opinions in the Authorization Decision on Kenya $20{ }^{1 / 43}$, in the Appeal Request Decision in $20{ }^{1 / 4}{ }^{1 / 4}$ and in the Confirmation of Charges Decision in 2oI2. ${ }^{4} 45$ The judge noted that the arguments presented had been excessively liberal. Likewise, he introduced a much stricter definition of the term organization by arguing that the position that had been defended by the majority of the members of the Chamber had been built on a human rights approach that was not impeccable and which clashed directly with the principle of legality set up in the RS. This contains the principle of the strict construction of crimes, the prohibition of analogy and the mandate to interpret the definition of a crime in favour of accused in the case of ambiguity. ${ }^{1 / 6}$

According to the dissenting opinion of Judge Kaul, this Decision implied a teleological interpretation of crimes against humanity. It could be said that this interpretation rested on the argument that the ultimate object of these crimes under international law was the protection of basic human values. The fact to extend the protection of these values seems to be the reason why admitting an extensive construction of the concept of organization of Article 7 (III) of the RS. ${ }^{147}$ In the opinion of Judge Kaul, this broader or more flexible definition would turn crimes against humanity into a term used to address all kinds of mass atrocities that were not strictly isolated or particular acts of violence, and included in the scope ratione personae of the ICC to a large number of organizations with the capacity to orchestrate a policy of committing the crimes included in crimes against humanity in a massive or systematic way, which could also be prosecuted in the places where they were committed, thereby disregarding the reasons that originally led to the definition of crimes against humanity as crimes under international law. ${ }^{14^{8}}$

Although it seems that, according to the opinion expressed by Judge Kaul, the approach adopted by the ICC could be wrong, and as stated by Robinson the so-called "victim-focused teleological

1/42 ICC-01/o9-02/II, Situation in the Republic ofKenya, Decision on the Prosecutor's Application for Summonses to Appear for Francis Kirimi Muthaura, Uhuru Muigai Kenyatta and Mohammed HusseinAli, 8 March 20 II, para. 22.

I43 ICC-oI/o9-9, Decision Pursuant to Article 15 of the Rome Statute on the Authorization of an Investigation into the Situation in the Republic of Kenya, $3^{\mathrm{I}}$ March 2010, see Dissenting opinion ofJudge Hans-Peter Kaul, para. 5 I.

I'4t ICC-or/o9-02/II, Situation in the Republic ofKenya, Decision on the Prosecutor's Application for Summonses to Appear for Francis Kirimi Muthaura, Uhuru Muigai Kenyatta and Mohammed Hussein Ali, 8 March 20II, Dissenting opinion ofJudge Hans-Peter Kaul.

${ }_{145}$ ICC-01/o9-02/II, Situation in the Republic of Kenya, Decision on the Confirmation of Charges Pursuant to Article 6I (7) (a) and (b) of the Rome Statute, 23 January $20 I_{2}$ Kenyatta case 2012. Dissenting opinion of Judge HansPeter Kaul.

${ }_{14}^{16}$ ICC-oI/o9-9, Decision Pursuant to Article I5 of the Rome Statute on the Authorization of an Investigation into the Situation in the Republic of Kenya, see Dissenting opinion of Judge Hans-Peter Kaul, para. $5^{\mathbf{I}}$

${ }^{147}$ C. Kress, "On the Outer Limits of Crimes against Humanity: The Concept of Organization within the Policy Requirement: Some Reflections on the March 2oIo ICC Kenya Decision” Leiden Journal of International Law, 23 , 2oIo, $8_{55}-8_{73}$, at $8_{59}$ [doi:Io.IoI7/So922 $\mathbf{I}_{5} 6_{5}$ Ioooo $\left._{4} \mathrm{I}_{5}\right]$

${ }_{4}^{1} 8$ ICC-OI/o9-9, Decision Pursuant to Article ${ }_{5}$ of the Rome Statute on the Authorization of an Investigation into the Situation in the Republic of Kenya, $3^{\mathrm{I}}$ March 20Iо, para. 43. 
reasoning" is one of the interpretative fallacies of international criminal law ${ }^{149}$ it has been accepted by a part of the specialized doctrine.

Some authors have concluded that the majority of Pre-Trial Chamber II in the Authorization Decision of a $20 I$ Io Kenyan investigation, as well as in subsequent decisions, did not exclude the possibility that non-state organizations, such as private groups, could be involved in crimes against humanity. This opinion found supported in commentary 5 to Article $2 I$ of the Draft Code of crimes against peace and security of mankind of $\mathrm{I}_{99} \mathrm{I}^{15^{\circ}}$ which referred to those individuals endowed with $d e$ facto power and organized into criminal gangs or groups, whose acts could fall within the scope of the Project of the ILC. ${ }^{15}$

De Filippo, for example, has pointed out that "the associative element, and its inherently aggravating effect, could eventually be satisfied by purely private criminal organizations, thus not finding sufficient reasons for distinguishing the gravity of patterns of conduct directed by "territorial" entities or by private groups, given the latter's acquired capacity to infringe basic human values". ${ }^{52}$ Robinson also suggests that "some organized entity directing, instigating or encouraging crimes" would qualify as an organization under the Statute of the ICC. ${ }^{53}$ Sadat, in the same vein, has cautioned that a limited application of the term organization of Article 7 (II) to organizations with state characteristics would ignore the development of international criminal law from Nuremberg. ${ }^{54}$

The failure to recognize the capacity of other actors than states to commit the most serious crimes against humanity making them responsible for their criminal policies and the failure to expand the jurisdiction ratione personae of the ICC, would mean not measuring or properly treating the serious nature and consequence of the new threats that contemporary economic abuses are for the humanity. ${ }^{\mathrm{I} 5}$

Therefore, it would be an exercise of a fair appreciation of reality, not only in terms of legal requirements, but also ethical and political, to move towards the integration organizations or groups of any economic nature within the scope of Article 7 of the Statute of Rome submitting them to the jurisdiction of the ICC when they are involved in crimes against humanity. This is an inherent part of a proposal for "economic crimes against humanity". ${ }^{156}$

I49 D. Robinson, "The identity crisis of international criminal law," Leiden Journal of International Law, 2I, 20o8, $9^{25} 5^{-963}$, at. 933-946 [doi:ı.ı.ı 7 /So922156508005463].

${ }^{15}$ Although not already mentioned in the Draft Code of $\mathrm{I}_{99} 6$

${ }^{5^{5}} \quad$ H. G. van der Wilt, "Trafficking in Human Beings: A Modern Form of Slavery or a Transnational Crime?" Amsterdam Center for International Law, No. 2014-07, Amsterdam Law School Research Paper No. 2014-13 (2014) 297-334 at 307 [https://dx.doi.org/I0.2139/ssrn.2393338]

${ }^{152}$ M. Di Fillipo, "Terrorist Crimes and International Co-operation: Critical Remarks on the Definition and Inclusion of Terrorism in the Category of International Crimes", European Journal of International Law, vol. I9, (2008) at $564-70$ https://doi.org/10.1093/ejil/chno27].

I53 D. Robinson, "Essence of Crimes against Humanity Raised by Challenges at ICC", Blog of the European Journal of International Law, EJIL Talk!, 27 September 2011.

${ }^{15} 4$ L. Sadat, "Crimes against Humanity in the Modern Age”, The American Journal of International Law, vol. Io7 (20I2) at 334-377 [doi: 0.5305/amerjintelaw.Io7.2.0334].

${ }_{55}$ M. Kremnitzer, "A Possible Case for Imposing Criminal Liability on Corporations in International Criminal Law,” Journal of International Criminal Justice, vol. 8 (2oIo) 9o9-9I8, at ${ }_{9} I_{5}$ [doi:Io.Iog3/jicj/mqqo36].

${ }^{15} 6$ It is important to note that the ILC Draft articles on prevention and punishment of crimes against humanity, in the Article 6 on the matter of criminalization under national law, includes a provision in the paragraph 8 to stablish the liability of legal person for the crimes against humanity in the following terms: "Subject to the 


\section{(b) A parallel concept of the policy element for "economic crimes against humanity"}

Recognizing that non-state or private actors may have the capacity to infringe basic human values and commit widespread and systematic attacks on the civilian population means that these acts must be committed in accordance with an organizational policy. ${ }^{157}$

Bassiouni, although he points out that Article 7 cannot be construed a new development for crimes against humanity, in particular its application to non-state actors, does claim that expanding the ratione materiae of the ICC towards entities such as the mafia, or even al-Qaeda, would go against the spirit of this article. ${ }^{158} \mathrm{He}$ further notes that in the case of accepting the involvement of non-state actors in these crimes, a new concept of policy element would have to be shaped, parallel to the traditional concept of the state policy. ${ }^{59}$ However, an amendment in this regard to the Statute of the ICC as an expression of the interpretation of the meaning of the term "policy of an organization" is considered distant. $^{160}$

This new concept of "organizational policy" should not only be inferred from a broader interpretation of the element of the policy, which has been carried out by the jurisprudence od ad hoc International Criminal Courts and the ICC, but should be endowed necessarily with new content.

In this vein, this content of the proposed concept of organizational policy would mean that it necessarily must confers entity to criminal acts: it must relates them and determines that they are not a consequence of fortuitous or isolated events; it must consist in the promotion of particular objectives, purposes and interests which are aimed at obtaining an economic profit, or maintaining a position or balance of economic-political power as a specific purpose; for those propose the illegal acts underlying crimes against humanity are intentionally committed or assuming a risk-oriented approach in the realization of the illegal acts.

This organizational policy by economic actors, as required by state policy, and following the jurisprudence of the ad hoc International Criminal Tribunals, it could be said that it need not be a formally adopted policy ${ }^{161}$ nor expressly or precisely stated ${ }^{162}$, nor strictly planned ${ }^{163}$, but could be

provisions of its national law, each State shall take measures, where appropriate, to establish the liability of legal persons for the offences referred to in this draft article. Subject to the legal principles of the State, such liability of legal persons may be criminal, civil or administrative", supra n. Io

${ }^{157}$ T. Rodenhauser, "Beyond state Crimes: Non-state Entities and Crimes against Humanity," Leiden Journal of International Law 27, 20I/4, 9I3-928, at 926. [doi:Io.10I7/So922I5651/0004I7].

${ }_{5}{ }^{8}$ M. C. Bassiouni, Crimes Against Humanity, supra n. 6g.

${ }^{159}$ Ibid, at $4^{2}$

${ }^{160}$ M. C. Bassiouni, supra n. 73 , at 585 .

${ }^{161}$ ICTR-96-4-T, The Prosecutor v. Jean-Paul Akayesu,Trial Chamber Judgemente, I, 2 September 1998, para. 580; ICTY-IT-94-I-A y IT-94-I-A bis, The Prosecutor v. Tadic, Appeals Chamber, Judgment in Sentencing Appeal Dissenting Opinion of the Judge Shahabuddeen, 26 February 20oo, para. 653; ICTR-96-3, The Prosecutor $v$. Georges Anderson Nderubumwe Rutaganda, Trial Chamber I, Judgment and Sentence, 6 December I999, para. 69; ICTR-96-I3-A, The Prosecutor v. Alfred Musema, Trial Chamber I, Judgment and Sentence, 27 January 2000 , para 204; ICC-oI/oy-oI/o7, Situation In The Democratic Republic of the Congo in the case of the Prosecutor $v$. Germain Katanga, Judgment pursuant to Article 74 of the Statute, 7 March 2014, para Ilog: ICC-o2/II-OI/II-432, Situation In The Republic OfCote D'Ivoire in the case of the Prosecutorv. Laurent Gbagbo, Decision adjourning the hearing on the confirmation of charges pursuant to Article 6I(7)(i) of the Rome Statute, 3 June 20I3, paras. 2 II, 2 I2 and $2 I_{5}$.

${ }^{162}$ ICTY IT-95-1/4, The Prosecutor v. Tihomir Blasick, Appeals Chamber, Judgement, 29 July 2004, para. 204.

${ }^{16}{ }_{3}$ ICC-oI/o4-oI/o7, Situation In The Democratic Republic of the Congo in the case of the Prosecutor v. Germain 
deduced from the repetition of acts, by the way in which the preparatory activities of the acts that give rise to the crimes are conducted ${ }^{164}$. It could be considered a policy of active promotion or encouragement ${ }^{165}$, notwithstanding a policy of deliberate omission, in exceptional circumstances, provided that it was aimed at favouring or facilitating an attack of an economic nature. ${ }^{166}$

Concluding and according to Carrillo Salcedo, the process of diffusion of power implies important changes, both in nature, and in the distribution of it among the different actors on the international society, not today exclusively state-like. ${ }^{167}$ Recent experiences have shown us that non-state actors can, and do, carry out the commission of crimes against humanity ${ }^{168}$ having revealed the capacity, strength and power necessary to victimize the vulnerable, and thus qualifies their behaviour as crimes under international law. This is why one of the most important challenges for international law in contemporary society is to regulate the activities of non-state actors, who have the capacity to infringe values that are subject to the protection of the international community, given the predominance of the economic paradigm in the composition of the new forms of the exercise of power and the profit policies that favour them.

International criminal law should move on these transformations and must legally address the power of non-state actors, preventing, prosecuting, and punishing the exercise of economic power that has definitively become a new leitmotiv of crimes of international law.

\section{(E) CONCLUSIONS}

The purpose of this work has been to study the possibilities offered by intern ational law to address the criminalization of the serious economic and financial abuses underlying a category called "economic crimes against humanity”.

The legal-positive regulation of crimes against humanity has been a historic milestone in the development and humanization process in international law. The purpose and foundation of this category of international crimes has been expressly the protection of human beings from the most aberrant behaviour committed in the exercise of abuse of political power, creating a system of $j u s$ puniendi and individual criminal responsibility in international law.

Due to the accelerated changes in the international society, such as the distribution and the exercise of power by state and no-state actors and the new social and economic threatens for the humanity, it is necessary to contemplate the protection of fundamental and universal principles and values not only by the customary o conventional law that prohibits crimes against humanity but for conceptual

Katanga, Judgment pursuant to Article 74 of the Statute, 7 March 2014, para. IIIo.

${ }^{16}{ }_{4}$ ICC-oI/o4-oI/o7, Situation in the Democratic Republic of the Congo in the case of the Prosecutor v. Germain Katanga, Judgment pursuant to Article 74 of the Statute, 7 March 2014, para IIo9; Iog; see also ICC-o2/II-oI/II ICC02/II-02/II, The Prosecutorv. Laurent Gbagbo and Charles Blé Goudé,Decision on Prosecution requests to join the cases of The Prosecutor $v$. Laurent Gbagbo and The Prosecutor v. Charles Blé Goudé and related matters, II March 2OI5, paras. 2II, $2 \mathrm{I}_{2}$ and $2 \mathrm{I} 5$.

${ }_{16}{ }_{5}$ ICC, Elements of Crimes, at. 10.

${ }^{166}$ Ibid.

${ }^{167}$ J. A. Carrillo Salcedo, "Derechos humanos y Derecho internacional”, ISEGORIA/22 (20oo).

${ }^{168}$ A. Gil Gil and E. Maculan, “Qué es el Derecho internacional penal” en A. Gil Gil and E. Maculan, supra n. 5 , at 40 . 
innovation of the legal mechanism necessary for the modernization and reform of international law.

The development of the category of "economic crimes against humanity" is an expression of these new tensions and challenges currently facing international law. The integral protection of the individual and peoples from the most serious economic and economic-political abuses is not easy to fit into the conventional architecture of the classical international system.

The category "economic crimes against humanity", which would cover economic abuses of serious nature and consequences due to having a general dimension that would affect fundamental universal human values recognized by the international community. However, this category are not currently part of the material scope of crimes against humanity included in the RS and. Thus, it would not be possible to use this instrument for the prosecution of these illegal acts, via connection with the crimes that are strictly enumerated in its Article, nor to demand international criminal responsibility for its perpetrators.

An opportunity of expanding the scope and content of crimes against humanity to face these challenges would have been expected from the ILC works for the elaboration of a convention on prevention and punishment of crimes against humanity. However, both in the four reports presented by the Special Rapporteur from 2015 to 2019 , as well as in the contributions made by the States, as well as other actors involved, there is no consensus on expanding the catalogue of crimes. In fact, the definition of crimes against humanity replicates article 7 of the RS following the consensus reached by the international community in this vein. The evolution of the Draft articles regarding the RS can befound in those aspects related to build up national laws and national jurisdiction with respect to crimes against humanity and to place states parties in a cooperative relationship on matters such as extradition and mutual legal assistance.

Despite the above, it is clear that the so-called economic crimes against humanity has an impact on vital areas for human beings and peoples, generating significant human, social, environmental and economic damages, which would be committed by entities, groups or organizations that would hold an extraordinary economic and economic-political power, and that would have a great capacity for victimization and acting with impunity. If international law once evolved by criminalizing the abuse of the political power of states against their own citizens, something that seemed inconceivable until after World War II, due to the lack of interference by this law in the state sovereignty, today it is necessary to advance towards an integral protection of human being from the abuses of economic and economic-political power by virtue of the progressive development of norms and institutions of international criminal law, even though it represents a huge legal challenge. 